\title{
PERANAN PEKERJA ANAK DI INDUSTRI KECIL SANDAL TERHADAP PENDAPATAN RUMAHTANGGA DAN KESEJAHTERAAN DIRINYA DI DESA PARAKAN, KECAMATAN CIOMAS, KABUPATEN BOGOR, JAWA BARAT
}

\author{
The Role of Child Labour in Small Industry of Sandals for Their Household Income and \\ Children's Welfare
}

Annisa Avianti*), dan Martua Sihaloho

Departemen Sains Komunikasi dan Pengembangan Masyarakat, Fakultas Ekologis Manusia, IPB

\begin{abstract}
Child labour is one of social phenomenon that its existenceis still ongoing even be complex. Child labor is a matter that can not be circumvented in the developing countries including Indonesia. Children who are working have role for contributing to family income, either directly or indirectly. The entry of children into the world of work can also have an impact for the welfare of the child. This case occurred in Desa Parakan, Kecamatan Ciomas, Kabupaten Bogor, Jawa Barat.The aims of this research are to know the factors that led to the emergence child labor and the impact of the workings of the child to their household income and children's welfare child.
\end{abstract}

Keywords: child labor, child welfare, household income

\section{ABSTRAK}

Pekerja anak merupakan salah satu fenomena sosial yang ada bahkan menjadi kompleks. Pekerja anak merupakan suatu hal yang tidak dapat dielakkan di negara berkembang termasuk di dalamnya Indonesia. Anak-anak yang bekerja berperan dalam menyumbang pendapatan keluarga, baik secara langsung maupun tidak langsung. Terlibatnya anak-anak dalam dunia kerja juga memiliki dampak terhadap kesejahteraan anak. Permasalahan ini terjadi di Desa Parakan, Kecamatan Ciomas, Kabupaten Bogor, Jawa Barat. Tujuan dari penelitian ini adalah untuk mengetahui faktor-faktor yang mendorong munculnya pekerja anak dan peranan dari anak yang bekerja terhadap pendapatan rumahtangganya serta kesejahteraan anak tersebut.

Kata kunci : kesejahteraan anak, pekerja anak, pendapatan rumahtangga

\section{PENDAHULUAN}

\section{Latar Belakang}

Adanya era globalisasi menyebabkan terjadinya perubahan struktur ekonomi di Indonesia, yang ditandai dengan semakin berkurangnya sektor pertanian dan semakin berkembangnya sektor industri. Perkembangan bidang industri di pedesaan menyebabkan terjadinya pergeseran kesempatan kerja dari pertanian kenon-pertanian. Semakin sempitnya lahan pertanian serta rendahnya keuntungan yang diberikan dari bekerja di bidang pertanian memaksa sebagian besar penduduk di pedesaan beralih haluan mencari pekerjaan di bidang non-pertanian. Sektor industri menjadi penting keberadaanya di tengah-tengah menurunnya pendapatan di bidang pertanian.

Jenis industri yang banyak berkembang di pedesaan saat ini adalah industri kecil. Hal ini lantaran umumnya industri besar hanya mampu menampung tenaga kerja yang relatif sedikit karena sifatnya yang padat modal. Industri kecil umumnya tidak membutuhkan pekerja dengan tingkat pendidikan dan keterampilan khusus sehingga dapat menyerap berbagai kalangan masyarakat. Selain itu, industri kecil juga sering memanfaatkan potensi lokal daerah dan juga untuk menjalankan industri ini tidak diperlukan alatalat dan teknologi modern yang membutuhkan biaya besar dalam penyediaan dan pengoperasiannya.

Perkembangan ketenagakerjaan di Indonesia tak luput dari peran pekerja anak, anak yang bekerja merupakan salah satu fenomena sosial yang eksistensi permasalahannya masih terus berlangsung bahkan menjadi kompleks (Pitriyan, 2006). Tenaga kerja anak pun merupakan suatu hal yang tidak bisa dielakkan di negara berkembang termasuk Indonesia.

Data BPS tahun 2010 menunjukkan bahwa dari jumlah keseluruhan anak berusia 5-17, sekitar 58,8 juta, 4,05 juta atau 6,9 persen di antaranya termasuk dalam kategori anak yang bekerja. Dari jumlah keseluruhan anak yang bekerja, 1,76 juta atau 43,3 persen merupakan pekerja anak. Sementara itu dari jumlah keseluruhan pekerja anak berusia $5-17,48,1$ juta atau 81,8 persen bersekolah, 24,3 juta atau 41,2 persen terlibat dalam pekerjaan rumah, dan 6,7 juta atau 11,4 persen tergolong sebagai 'idle', yaitu tidak bersekolah, tidak membantu di rumah dan tidak bekerja. Lebih lanjut data BPS tahun 2009 menyebutkan bahwa terdapat sekitar 10,4 juta anak usia 5-17 tahun yang bekerja di sektor industri. 
Munculnya pekerja anak di industri kecil yang terdapat di pedesaan ini umumnya terjadi lantaran tuntutan ekonomi keluarga pedesaan yang sebagian besar masih miskin. Pendapatan orangtua yang sedikit dan tidak mampu lagi memenuhi kebutuhan rumahtangga memaksa anak-anak untuk turut bekerja (Muchidin dan Nachrowi,1997). Akan tetapi, kehidupan anak-anak yang berada di tengahtengah kegiatan industry kecil secara tidak langsung menyebabkan mereka menginternalisasi dengan kegiatan tersebut dan kemudian baik secara sadar maupun tidak mereka terlibat di dalamnya.

Anak-anak yang bekerja di industri kecil ini berperan dalam menyumbangkan pendapatan kepada keluarganya baik secara langsung maupun tidak langsung. Dengan bekerjanya seorang anak dalam keluarga, maka akan mengurangi jumlah tanggungan keluarga tersebut. Namun, di sisi lain bekerjanya seorang anak juga berdampak pada terpenuhinya hak mereka untuk mendapatkan pendidikan yang layak serta hak-hak lain yang mestinya diperoleh anak-anak seusia mereka.

\section{Perumusan Masalah}

Sejalan dengan uraian di atas, penelitian ini menitikberatkan permasalahan yang dirumuskan sebagai berikut :

1. Apa faktor-faktor yang mendorong munculnya pekerja anak dilihat dari karakteristik pekerja anak, keluarga pekerja dan pekerjaan?

2. Bagaimana peranan dari anak yang bekerja terhadap pendapatan rumah tangganya serta kesejahteraan anak tersebut?

\section{Tujuan Penelitian}

Berdasarkan perumusan masalah yang telah dipaparkan di atas, maka tujuan dari penelitian ini adalah untuk:

1. Menganalisis faktor-faktor yang mendorong munculnya pekerja anak dilihat dari karakteristik pekerja anak, keluarga pekerja dan pekerjaan.

2. Menganalisis peranan dari anak yang bekerja terhadap pendapatan rumah tangganya serta kesejahteraan anak tersebut.

\section{Kegunaan Penelitian}

Penelitian ini diharapkan dapat memberikan kegunaan, yaitu:

1. Akademisi, di mana penelitian ini diharapkan dapat menjadi referensi bagi peneliti yang ingin mengkaji permasalahan ketenagakerjaan, khususnya yang berkaitan dengan pekerja anak dan juga untuk meningkatkan kemampuan peneliti dalam menerapkan berbagai konsep ketenagakerjaan di.

2. Masyarakat, di mana penelitian ini diharapkan dapat berdampak positif bagi masyarakat, khususnya pekerja anak, untuk menambah pengetahuan tentang kajian permasalahan ketenagakerjaan.

3. Pemerintah, di mana penelitian ini diharapkan dapat memberikan masukan atau dijadikan bahan pertimbangan bagi para penentu kebijakan (pemerintah) dalam merencanakan, mengambil keputusan dan membuat kebijakan tentang ketenagakerjaan, khususnya tenaga kerja yang masih di bawah umur.

\section{PENDEKATAN TEORITIS}

\section{Konsep anak}

Kamus Besar Bahasa Indonesia menyebutkan pengertian anak yaitu bahwa anak adalah keturunan kedua, pengertian lainnya adalah manusia yang masih kecil. Anak-anak ialah baik laki-laki maupun perempuan yang berusia di bawah 18 tahun. Definisi ini sesuai dengan aturan perundangundangan sebagai berikut:

1. Konvensi Hak Anak yang telah diratifikasi pada 1990 (melalui Keputusan Presiden No 36) mendefinisikan usia di bawah 18 sebagai anak-anak kecuali, berdasarkan hukum, kedewasaan telah dicapai lebih awal,

2. Undang-Undang Republik Indonesia nomor 23 Tahun 2002 Tentang Perlindungan Anak menyatakan bahwa anak adalah seseorang yang belum berusia 18 (delapan belas) tahun, termasuk anak yang masih dalam kandungan,

3. Undang-Undang Republik Indonesia nomor 13 Tahun 2003 Tentang Ketenagakerjaan menyatakan bahwa anak adalah setiap orang yang berumur dibawah 18 (delapan belas) tahun.

\section{Konsep Pekerja Anak}

Pekerjaan sebagaimana didefinisikan oleh ILO (2008) adalah merupakan suatu kegiatan ekonomi. Kegiatan ekonomi mencakup semua pekerjaan yang dibayar dan beberapa tipe pekerjaan yang tidak dibayar, termasuk produksi barang-barang untuk dipakai sendiri. Apakah dibayar atau tidak, kegiatan atau pekerjaan ini dapat dilakukan baik di sektor formal ataupun informal dan di daerah perkotaan ataupun di pedesaan.

Secara umum pengertian pekerja anak sebagaimana yang dijelaskan oleh Suyanto dan Hariadi (2003) dalam Charda (2010) adalah anak-anak yang melakukan pekerjaan secara rutin untuk orangtuanya atau untuk orang lain yang membutuhkan sejumlah besar waktu, dengan menerima imbalan atau tidak.

Sementara itu Vandenberg menjelaskan konsep pekerja anak sebagai "pekerja anak adalah istilah yang digunakan untuk mengacu pada anak yang melakukan pekerjaan yang merusak kesejahteraan dan menghalangi pendidikan, perkembangan, dan masa depan anak tersebut" (Vandenberg , 2009). Lebih lanjut Vandenberg (2009) menggunakan dua istilah yaitu "anak yang bekerja" dan "anak yang aktif secara ekonomi" - tidak termasuk pekerjaan rumah yang dilakukan di rumah mereka sendiri-yang keduanya mengacu pada pekerjaan yang dilakukan seorang anak lebih dari satu jam selama seminggu baik diupah maupun tidak diupah, permanen ataupun sambilan, dan legal ataupun illegal.

Keputusan Presiden No. 59/2002 menjabarkan 13 bentuk Pekerjaan Terburuk dari Pekerja Anak, yaitu sebagai berikut:

1. Mempekerjakan anak-anak sebagai pelacur;

2. Mempekerjakan anak-anak di pertambangan; 
3. Mempekerjakan anak-anak sebagai penyelam mutiara;

4. Mempekerjakan anak-anak di bidang konstruksi;

5. Menugaskan anak-anak di anjungan penangkapn ikan lepas pantai (yang di Indonesia disebut jermal);

6. Mempekerjakan anak-anak sebagai pemulung;

7. Melibatkan anak-anak dalam pembuatan dan Kegiatan yang menggunakan bahan peledak;

8. Mempekerjakan anak-anak di jalanan;

9. Mempekerjakan anak-anak sebagai tulang Punggung keluarga;

10. Mempekerjakan anak-anak di industri rumah tangga (cottage industries);

11. Mempekerjakan anak-anak di perkebunan;

12. Mempekerjakan anak-anak dalam kegiatan-kegiatan yang berkaitan dengan usaha penebangan kayu untuk industri atau mengolah kayu untuk bahan bangunan dan pengangkutan kayu gelondongan dan kayu olahan;

13. Mempekerjakan anak-anak dalam berbagai industri dan kegiatan yang menggunakan bahan kimia berbahaya.

\section{Konsep Industri Kecil}

Hasibuan (1993) mengungkapkan bahwa pengertian industri sangat luas yang dapat meliputi lingkup makro dan mikro. Secara mikro, industri merupakan kumpulan perusahaan-perusahaan yang menghasilkan barang-barang yang homogeni atau barang-barang yang mempunyai sifat saling menggantikan secara erat. Sementara itu, dari segi makro, industri adalah kegiatan ekonomi yang menciptakan nilai tambah.

Salah satu bentuk industri adalah industri pengolahan. BPS (2009) memberikan definisi tentang industri pengolahan yaitu sebagai industri yang meliputi kegiatan ekonomi/ lapangan usaha di bidang perubahaan secara kimia atau fisik dari bahan, unsur atau komponen menjadi produk baru. Perubahan, pembaharuan atau rekonstruksi yang pokok dari barang secara umum diperlakukan sebagai industri pengolahan. Unit industri pengolahan digambarkan sebagai pabrik, mesin atau peralatan yang khusus digerakkan dengan mesin dan tangan. Termasuk kategori industri pengolahan di sini adalah unit yang mengubah bahan menjadi produk baru dengan menggunakan tangan, kegiatan maklon atau kegiatan penjualan produk yang dibuat di tempat yang sama di mana produk tersebut dijual dan unit yang melakukan pengolahan bahan-bahan dari pihak lain atas dasar kontrak. Perusahaan industri pengolahan dibagi dalam 4 golongan yaitu :

1. Industri Besar (banyaknya tenaga kerja 100 orang atau lebih)

2. Industri Sedang (banyaknya tenaga kerja 20-99 orang)

3. Industri Kecil (banyaknya tenaga kerja 5-19 orang)

4. Industri Rumah Tangga (banyaknya tenaga kerja 1-4 orang)

Saleh (1986) memberikan definisi tentang industri kecil yaitu sebagai sebuah unit usaha yang menyerap tenaga kerja antara 5 sampai 19 orang. Menurut Saleh (1986) terdapat beberapa alasan kuat yang mendasari pentingnya keberadaan industri kecil dan rumah tangga dalam perekonomian Indonesia. Alasan-alasan itu antara lain:
1. Sebagian besar lokasi industri kecil dan rumah tangga berlokasi di daerah pedesaan, sehingga apabila dikaitkan dengan kenyataan bahwa lahan pertanian yang semakin berkurang, maka industri kecil dan rumah tangga di pedesaan dapat menyerap tenaga kerja di daerah pedesaan.

2. Kegiatan industri kecil dan rumah tangga menggunakan bahan baku dari sumber-sumber di lingkungan terdekat yang menyebabkan biaya produksi dapat ditekan rendah.

3. Dengan tingkat pendapatan masyarakat yang relatif rendah serta harga produk industri kecil dan rumah tangga yang murah akan memberikan peluang agar tetap bisa bertahan.

4. Tetap adanya permintaan terhadap produk yang tidak diproduksi secara besar-besaran, misalnya batik tulis, anyam-anyaman, dan lain-lain.

\section{Karakteristik Pekerja Anak}

Karakteristik demografi pekerja anak sebagaimana yang dikemukakan oleh Priyambada et al (2002), meliputi umur dan gender. Semakin tua anak makin tinggi potensi pendapatan yang dapat diperoleh anak tersebut, sehingga akan lebih tinggi pula peluang anak tersebut untuk masuk ke dunia kerja. Sementara dalam hal gender, fenomena pekerja anak lebih umum terjadi di kalangan anak laki-laki dibandingkan kalangan perempuan.

Selain karakterstik demografi tersebut, Sukindari (2004) dan Asih (2007) mengemukakan tingkat pendidikan sebagai karakteristik pekerja anak dimana anak yang bekerja umumnya berpendidikan rendah atau putus sekolah. Kemiskinan merupakan faktor utama yang mendorong putus sekolah anak-anak dimana orangtua terpaksa memberhentikan anak-anak mereka untuk bersekolah karena tidak adanya biaya. Selain itu, kelanjutan dari kemiskinan tadi, mereka harus bekerja sehingga tidak punya cukup waktu untuk serius belajar sembari tetap bekerja.

Pengalaman kerja juga merupakan karakteristik pekerja anak sebagaimana yang diungkapkan oleh Sukindari (2004). Pengalaman kerja tiap anak tentunya berbeda karena mereka memasuki lapangan kerja pada waktu yang berbeda dan makin lama mereka bekerja, makin tinggi pengalaman kerja mereka. Selain itu seringnya berpindah pekerjaan akan menyebabkan rendahnya pengalaman kerja pekerja anak karena mereka harus beradaptasi ulang dengan pekerjaan dan lingkungan kerjanya yang baru.

\section{Karakteristik Rumah tangga}

Terdapat empat karakteristik rumah tangga anak yang bekerja sebagaimana yang diungkapkan oleh Pitriyan (2006) adalah sebagai berikut:

1. Jenis kelamin kepala rumahtangga. Kepala rumahtangga perempuan akan meningkatkan peluang anak untuk bekerja Hal karena kepala rumahtangga perempuan cenderung berpenghasilan lebih rendah daripada kepala rumahtangga laki-laki.

2. Status pekerjaan kepala rumahtangga. Sektor yang melibatkan banyak pekerja, baik formal maupun 
informal akan meningkatkan peluang terlibatnya anak dalam bekerja.

3. Beban tanggungan keluarga. Semakin tinggi jumlah anggota rumahtangga, semakin berat beban keluarga sehingga meningkatkan peluang dikirimnya anak ke pasar tenaga kerja.

4. Kelas pendapatan rumahtangga. Anak yang hidup di rumahtangga dengan pendapatan menengah ke atas lebih besar dari kemungkinan untuk bersekolah dibandingkan bekerja.

Priyambada (2002) juga mengemukakan mengenai karakteristik rumahtangga pekerja anak yang serupa dengan Pitriyan (2007), hanya saja Priyambada menambahkan tingkat pendidikan kepala rumahtangga sebagai karakteristik rumahtangga pekerja anak. Pekerja anak yang berasal dari rumahtangga yang dikepalai oleh orang dengan tingkat pendidikan yang tinggi akan sangat sulit dijumpai karena sang kepala rumahtangga akan memiliki pendapatan yang lebih besar sehingga anak tidak perlu bekerja serta memiliki pemahaman yang lebih tentang pentingnya pendidikan.

\section{Karakteristik Pekerjaan}

Serupa dengan tenaga kerja dewasa, anak yang bekerja juga terlibat hampir di dalam semua lapangan pekerjaan. Seperti juga tenaga kerja dewasa, sebagian besar anak-anak bekerja pada tiga lapangan pekerjaan besar di Indonesia, yakni: pertanian, perdagangan, dan industri pengolahan. BPS dan ILO (2009) dalam Pekerja Anak di Indonesia (2009), menyebutkan karakteristik pekerjaan yang meliputi meliputi jenis pekerjaan, sistem pengupahan dan jumlah jam kerja serta status pekerjaan dan tempat kerja kedalam karakteristik pekerjaan. Dengan demikian, terdapat lima karakteristik pekerjaan yang meliputi:

1. Jenis pekerjaan, yakni apakah pekerjaan tersebut tergolong pekerjaan yang ringan atau berat dan memerlukan keterampilan khusus atau tidak,

2. Sistem pengupahan, yakni mencakup upah dan gaji yang diterima pekerja dan sistemnya (apakah borongan atau satuan),

3. Jam kerja, yakni waktu yang dicurahkan untuk bekerja,

4. Status pekerjaan, yakni apakah dia termasuk buruh/ pegawai, berusaha sendiri atau pekerja yang tak dibayar,

5. Tempat kerja, yakni tempat yang digunakan untuk bekerja, apakah itu tetap atau tidak tentu.

\section{Faktor-Faktor yang Mendorong Anak Bekerja}

Masuknya anak-anak ke dunia kerja dipengaruhi oleh beberapa faktor yang berhubungan yang mana faktor-faktor tersebut saling berhubungan satu sama lain. Vandenberg (2009) mendefinisikan lima faktor kunci dimana tiga yang pertama adalah faktor penarik sedangkan sisanya merupakan faktor pendorong. Kombinasi dari faktor penarik dan pendoronglah yang memberikan kontribusi terhadap tetap adanya pekerja anak. Berikut akan dijelaskan kelima faktor tersebut.

Pertama adalah kemiskinan. Kemiskinan memainkan peran utama dalam munculnya pekerja anak. Rumahtangga yang tergolong menengah ke bawah akan sangat mungkin untuk mengirim anaknya bekerja demi membantu ekonomi keluarga. Kemiskinan rumahtangga ini dapat dilihat melalui tingkat kesejahteraan rumahtangga tersebut yang dapat diamati melalui pengeluaran per kapita rumahtangga tersebut.

Priyambada et al, (2002) menyatakan bahwa semakin kecil pengeluaran rumahtangga per kapita, semakin besar kemungkinan anak-anak di rumahtangga tersebut akan memasuki pasar tenaga kerja. Namun, walaupun kemiskinan adalah faktor yang penting dalam mempengaruhi keputusan keluarga akan pekerja anak, itu bukanlah faktor tunggal.

Kedua adalah akses pendidikan. Alternatif bila anak tidak bekerja adalah sekolah. Namun jika orangtua tidak mampu membayar biaya pendidikan (termasuk didalamnya transportasi ke sekolah, uang jajan, uang buku, dll), anakanak tidak dapat bersekolah dan harus bekerja untuk keluarga atau untuk orang lain. Selain masalah biaya, jika orangtua merasa bahwa anak-anak mereka tidak mendapatkan pendidikan di sekolahnya, mereka akan kurang termotivasi untuk mengirimkan anak-anak mereka ke sekolah.

Ketiga adalah norma dan sikap sosial. Stigma masyarakat mengenai pekerja anak berbeda di tiap masyarakat. Dalam masyarakat dimana stigma tersebut rendah, orangtua tidak akan terpengaruh oleh tekanan tetangga untuk tetap menyekolahkan anak-anak mereka dan mereka tetap akan mempekerjakan anak-anaknya.

Keempat adalah permintaan dari rumah tangga, pertanian keluarga atau usaha keluarga. Banyak anak-anak yang bekerja untuk orangtua mereka. Bila anak-anak melakukan pekerjaan rumahtangga, maka orangtua mereka bisa bekerja di tempat lain untuk menambah penghasilan.

Kelima adalah permintaan dari usaha-usaha lain. Anakanak adalah tenaga kerja yang murah dan banyak jumlahnya sehingga banyak usaha-usaha kecil yang suka mempekerjakan pekerja anak. Selain itu pekerja anak juga lebih mudah diatur karena mereka lebih tidak mampu untuk mempertahankan hak dan kepentingan mereka dibandingkan orang dewasa.

\section{Konsep Kesejahteraan Anak}

White et al, (2002) menjelaskan bahwa kesejahteraan anak merupakan komponen penting dari kesejahteraan sebuah negara secara keseluruhan karena populasi anak terutama di negara berkembang mencapai 35 bahkan 50 persen jumlah penduduk. Anak berbeda dengan orang dewasa dimana kesejahteraan anak masa kini akan menentukan kesejahteraan sebuah negara di masa mendatang. Oleh karena itu, indikator kesejahteraan anak berbeda dari 'standar' indikator kemiskinan, karena indikator tersebut perlu mencerminkan posisi khusus anak-anak .

Undang-Undang No 23 Tahun 2002 menjelaskan bahwa anak merupakan generasi muda penerus bangsa yang memiliki peran strategis dan mempunyai ciri dan sifat khusus yang menjamin kelangsungan eksistensi bangsa dan negara pada masa depan. Agar setiap anak mampu memikul tanggungjawab tersebut, mereka perlu mendapat kesempatan yang seluas-luasnya untuk tumbuh dan 
berkembang dengan wajar baik secara rohani, jasmani maupun sosial.

Kesejahteraan anak sebagaimana yang tertuang dalam Undang-Undang No 4 Tahun 1979 adalah suatu tata kehidupan dan penghidupan anak yang dapat menjamin pertumbuhan dan perkembangannya dengan wajar, baik secara rohani, jasmani maupun sosial. Orangtua merupakan institusi utama yang bertanggungjawab dan berkewajiban untuk memelihara dan mendidik anak sehingga anak dapat tumbuh dan berkembang dan mencapai kesejahteraannya. Namun diperlukan juga adanya pihak lain yang melindunginya.

\section{Pendapatan Anak dan Pendapatan Rumahtangga}

Terdapat beberapa pengertian tentang pendapatan. Tohar (2000) menyatakan bahwa secara umum ada dua segi pengertian dari pendapatan, yaitu dalam arti riil dan dalam arti jumlah luar. Pendapatan dalam arti riil adalah nilai jumlah produksi barang dan jasa yang dihasilkan oleh masyarakat selama jangka waktu tertentu. Sedangkan pendapatan dalam arti jumlah uang merupakan penerimaan yang diterimanya, bisa dalam bentuh upah dari bekerja atau uang hasil penjualan, dan lain sebagainya. Dengan demikian dapat dikatakan bahwa pendapatan anak adalah jumlah uang yang diterima anak dari hasil dia bekerja sebagai tenaga kerja atau uang yang diterima anak dari hasil berjualan.

Sementara itu pendapatan rumahtangga berbeda dengan pendapatan individu. Mengutip dari http://www.investopedia. com tentang household income definition, pendapatan rumahtangga merupakan:

\begin{abstract}
"The combined gross income of all the members of a household who are 15 years old and older. Individuals do not have to be related in any way to be considered members of the same household. Alternatively, household income is the combined income of all members of a household who jointly apply for credit. Household income is an important risk measure used by lenders for underwriting loans"
\end{abstract}

Dari definisi tersebut, terlihat bahwa pendapatan rumahtangga merupakan total dari pendapatan anggota- anggota dalam rumahtangga tersebut. Dalam memenuhi kebutuhan hidupnya, sebuah rumahtangga berusaha meningkatkan pendapatannya melalui berbagai strategi pola nafkah. Salah satunya adalah strategi alokasi sumberdaya dimana karena terjadi keterbatasan sumberdaya ekonomi maka dengan terpaksa rumahtangga-rumahtangga miskin harus melibatkan seluruh sumberdaya manusia di dalam rumahtangga tersebut. Tak terkecuali anak-anak mereka yang masih di bawah umur (Asih, 2007). Oleh karena itu keberadaan pekerja anak diinginkan karena dapat memberikan kontribusi untuk pendapatan rumahtangga.

\section{Kontribusi Pekerja Anak terhadap Pendapatan Rumahtangga dan Kesejahteraan Dirinya}

Masuknya anak ke dalam dunia kerja tentunya ditujukan untuk memperbaiki kesejahteraan keluarganya. Seperti yang telah dijelaskan sebelumnya, melibatkan anak untuk bekerja merupakan salah satu strategi pencarian nafkah guna menambah pendapatan rumahtangga. Sukindari (2004) menganalisis empat hal yang memiliki keterkaitan hubungan dengan kontribusi pekerja anak terhadap pendapatan keluarga, yaitu:

1. Karakteristik individu dimana pekerja anak yang kompeten akan memberikan kontribusi yang lebih tinggi terhadap pendapatan keluarga. Biasanya pekerja anak yang kompeten berasal dari keluarga yang tergolong miskin yang bekerja karena keinginannya sendiri dan memiliki motivasi kerja yang tinggi.

2. Upah yang diperoleh dimana makin tinggi upah yang diperoleh pekerja anak maka makin tinggi pula kontribusi yang akan diberikan anak terhadap pendapatan keluarga. Kontribusi pendapatan yang tinggi disebabkan oleh tuntutan ekonomi keluarga yang memang membutuhkan uang demi keberlangsungan hidup keluarga. Namun hasil penelitian Sukindari (2004) menunjukan bahwa hubungan antara upah yang diterima pekerja anak dengan kontribusi mereka terhadap pendapatan keluarga rendah karena seringkali upah pekerja anak digunakan oleh mereka sendiri untuk memenuhi kebutuhan pribadi mereka seperti membeli keperluan sekolah dan jajan.

3. Jenis pekerjaan dimana semakin sulit jenis pekerjaan yang dilakukan akan memberikan upah yang lebih besar dan kemudian meningkatkan kontribusi terhadap pendapatan keluarga.

4. Status sosial ekonomi keluarga dimana rendahnya status sosial ekonomi rumahtangga pekerja menyebabkan beban tanggungan rumahtangga yang besar sehingga anak-anak yang bekerja biasanya akan menyerahkan hampir seluruh upah yang diterimanya kepada orangtuanya.

Bekerjanya seorang anak tentunya akan memberikan perubahan-perubahan terhadap kesejahteraan anak tersebut. United Nations Educational, Scientific and Cultural Organization (UNESCO) (1995) dalam White et al(2002) mengusulkan satu set langkah-langkah untuk mengukur kesejahteraan anak-anak dalam tiga bidang area, yaitu: (1) keluarga: laki-laki dan perempuan melek huruf, usia, kesuburan total; (2) masyarakat: GNP per kapita, akses ke layanan kesehatan, dan akses terhadap air yang aman, dan (3) pendidikan: kelompok usia yang terdaftar dalam pendidikan Sekolah Dasar maupun sekolah menengah serta rasio pendaftaran. Dengan demikian, kontribusi pekerja anak terhadap kesejahteraan anak itu sendiri dapat dilihat melalui:

1. Pendidikan. Bekerja penuh waktu menghambat anak untuk mendapatkan pendidikan. Mereka tidak belajar dasar-dasar membaca, menulis, dan aritmatika dan tidak dapat mengembangkan proses berpikir yang lebih baik. Hal ini menghalangi potensi ekonomi anak di masa depan. Efeknya, anak akan terjebak dalam pekerjaan rendahan bergaji rendah (Vandenberg, 2009).

2. Kesehatan dan keselamatan anak-anak. Anak-anak lebih rentan daripada orang dewasa terhadap bahaya-bahaya pekerjaan yang ada karena mereka masih dalam masa pertumbuhan. Tingkat risiko bagi para pekerja anak lebih ditentukan oleh tugas dan kondisi-kondisi di mana mereka bekerja daripada oleh industri spesifik tertentu. Selain itu, karena mereka masih kurang dalam kedewasaan dan pengalaman, secara fisik lebih kecil dan sering kurang gizi, anak-anak terpengaruh oleh lamanya jam kerja dan zat- 
zat berbahaya. Mereka juga rentan terhadap cedera dari mesin-mesin yang sebenarnya dirancang untuk orang dewasa (Vandenberg, 2009).

3. Kondisi emosional anak. Beberapa literature menyebutkan bahwa anak yang bekerja seringkali memperoleh perlakuan kasar di tempat kerjanya. Pada anak yang bekerja di perkebunan, misalnya, sebagaimana hasil yang didapatkan dari penelitian Yayasan Prakarsa Swadaya Masyarakat (YPSM) (2007) tentang pekerja anak di perkebunan tembakau Jember, serta penelitian ILO (2007) tentang pekerja anak di perkebunan tembakau Sumatera Utara menyebutkan bahwa para pekerja anak terkadang memperoleh perlakuan buruk bersifat nonfisik seperti dihardik, dimarahi dan diomeli yang biasanya disebabkan bila pekerja melakukan kesalahan. Pada perkebunan tembakau di Jember, bahkan terdapat juga beberapa pelecehan seksual yang diterima oleh para buruh anak walaupun dalam jumlah yang sedikit seperti disiuli dan dijamah bagian tubuh sensitifnya.

\section{Kerangka Pemikiran}

Keikutsertaan anak dalam mencari nafkah tidak terlepas dari berbagai faktor. Terdapat faktor pendorong yang mendorong rumahtangga untuk turut serta mempekerjakan anak mereka sebagai tenaga kerja yang terdiri dari pendapatan rumahtangga, akses pendidikan, serta norma dan sikap sosial dalam masyarakat yang dianut pula oleh rumahtangga terkait dengan anak yang bekerja. Dalam rumahtangga yang tingkat ekonominya rendah yang mana dapat dilihat melalui pengeluaran per kapita rumahtangga tersebut, mereka akan mengalokasikan seluruh sumberdaya yang ada untuk membantu meningkatkan pendapatan keluarga, termasuk anak-anak mereka sendiri. Terkait dengan tingkat ekonomi yang rendah di suatu rumahtangga, maka akses pendidikan anak-anak pada keluarga tersebut juga kurang lantaran tidak mampunya membayar biaya pendidikan.

Kurangnya akses ke pendidikan akan menyebabkan anak mencari kesibukan lain seperti bekerja. Ditambah lagi bila terdapat norma dan sikap sosial tertentu yang timbul di masyarakat yang menganggap bahwa tidak perlu pendidikan yang tinggi pun sudah dapat bekerja dan menghasilkan uang, akan terus mendorong anak untuk bekerja ketimbang bersekolah. Karakteristik individu pekerja anak dan karakteristik rumahtangga pekerja dapat membuat faktor pendorong bagi seorang anak untuk masuk ke lapangan pekerjaan.

Selain adanya faktor pendorong, terdapat pula faktor penarik yang menarik anak-anak untuk turut serta bekerja. Faktor penarik ini terdiri dari permintaan dari rumahtangga yang mana banyak usaha rumahtangga yang turut mempekerjakan anak mereka sendiri pada usaha mereka tersebut. Karakteristik dari pekerjaan yang ada akan menimbulkan faktor penarik anak untuk masuk ke dunia kerja.

Bila anak-anak melakukan pekerjaan rumahtangga, maka orangtua mereka bisa bekerja di tempat lain untuk menambah penghasilan. Anak-anak adalah tenaga kerja yang murah dan banyak jumlahnya sehingga banyak usaha-usaha kecil yang suka mempekerjakan pekerja anak. Ditambah lagi dengan sifat pekerja anak juga lebih mudah diatur sehingga permintaan akan tenaga kerja anak pun juga datang dari usaha-usaha lain di luar usaha rumahtangga. Kesemua faktor-faktor tersebut menyebabkan munculnya fenomena pekerja anak.

Anak yang bekerja dalam suatu rumahtangga baik secara langsung maupun tidak langsung berpengaruh terhadap pendapatan rumahtangganya karena bagaimanapun juga ketika ada tambahan anggota keluarga yang turut bekerja mencari nafkah maka pendapatan rumahtangga tersebut juga akan meningkat. Namun bekerjanya seorang anak juga membawa dampak terhadap kesejahteraan anak itu sendiri seperti pada kesehatannya, pendidikan anak tersebut serta kondisi emosional sang anak.

\section{Hipotesis}

Hipotesis penelitian ini disajikan sebagai berikut:

1. Karakteristik pekerja anak dan karakteristik rumahtangga memiliki pengaruh terhadap faktor pendorong munculnya pekerja anak

2. Karakteristik pekerjaan memiliki pengaruh terhadap faktor penarik anak bekerja

3. Bekerjanya seorang anak memiliki pengaruh terhadap peningkatan pendapatan rumahtangga dan kesejahteraan anak tersebut

\section{METODE PENELITIAN}

\section{Lokasi dan Waktu Penelitian}

Lokasi yang digunakan sebagai tempat penelitian adalah Desa Parakan, Kecamatan Ciomas, Kabupaten Bogor. Alasan dipilihnya desa tersebut sebagai desa penelitian adalah dengan dasar pertimbangan: a) Desa tersebut merupakan sentra industri sandal yang dikenal cukup lama oleh masyarakat, b) industri sandal memiliki pekerjaan-pekerjaan yang cukup ringan yang memungkinkan anak-anak terlibat didalamnya, dan c) pada kenyataannya usaha pembuatan sandal ini hampir semua melibatkan anak-anak sebagai tenaga kerjanya. Lamanya penelitian ini adalah selama tiga bulan, dari bulan Oktober sampai Desember 2011.

\section{Teknik Pengumpulan Data}

Jenis data yang digunakan dalam penelitian ini adalah data primer dan sekunder. Data primer didapat melalui penilitian langsung dengan menggunakan kuesioner dan wawancara bebas, sementara data sekunder didapat dari kantor Desa Parakan. Para responden tersebut adalah rumahtangga yangmemiliki anak laki-laki atau anak perempuan berumur 5-17 tahun yang bekerja pada industri rumahtangga sandal di Desa Parakan. Para informan adalah aparat pemerintah di tingkat Desa ataupun kecamatan serta dinas-dinas instansi yang terkait, orangtua dari pekerja anak serta pemilik bengkel sandal Metode yang dipakai dalam penelitian ini adalah wawancara, observasi dan dokumentasi. Sementara itu pendekatan yang digunakan adalah pendekatan kuantitatif dengan menggunakan kuesioner dan juga pendekatan kualitatif guna memberikan pemahaman yang mendalam dan terperinci terhadap suatu peristiwa atau gejala sosial dengan cara melakukan wawancara mendalam dengan informan terkait dengan fenomena pekerja anak yang terdapat di Desa Parakan, Kecamatan Ciomas tersebut. 
Populasi dalam penelitian ini adalah seluruh rumahtangga yang memiliki anak yang bekerja di Desa Parakan yang yang bekerja baik digaji maupun tidak digaji dan populasi sasaran dalam penelitian ini adalah seluruh rumah tangga yang memiliki anak-anak yang bekerja secara produktif dalam batas umur antara 5-17 tahun dengan unit analisis rumahtangga pekerja anak. Populasi ini didapat dengan sebelumnya terlebih dahulu dilakukan sensus terhadap seluruh rumahtangga yang ada di Desa Parakan, kemudian hasil dari sensus rumahtangga tersebut dipilih rumahtangga yang didalamnya terdapat anak yang turut bekerja di industri sandal. Responden ditentukan dengan teknik dari Nonrandom Sampling.

Pemilihan dengan teknik ini lantaran jumlah populasi yang ada di Desa Parakan hanya berjumlah 31 rumahtangga, maka seluruh populasi tersebut menjadi responden. Responden diwawancarai dengan kuesioner yang telah disusun. Jumlah sampel yang akan dijadikan responden berjumlah 31 orang. Jumlah ini dirasa cukup untuk memenuhi reliabilitas dan validitas data.

Selain responden, juga dipilih sejumlah informan yang berkaitan dengan tujuan penelitian yaitu aparat pemerintahan setempat guna memperoleh data mengenai kondisi sosial ekonomi rumahtangga di desa tersebut serta pemilik bengkel guna mengetahui secara rinci pekerjaan di bengkel sandal.

\section{Teknik Pengolahan dan Analisis Data}

Data yang telah dikumpulkan dianalisis menggunakan analisis deskriptif dan tabulasi silang. Langkah yang dilakukan setelah seluruh data terkumpul adalah melakukan pengkodean data. Setelah pengkodean, tahap berikut adalah persentase jawaban responden yang dibuat dalam bentuk tabulasi frekuensi maupun tabulasi silang.

Data yang diperoleh diolah secara statistik deskriptif dengan menggunakan program komputer Microsoft Excel 2007 serta SPSS Versi 16. Selain analisis data kuantitatif, dilakukan pula analisa data kualitatif dengan mengutip hasil pembicaraan dengan responden dan informan dan disampaikan secara deskriptif untuk mempertajam hasil penelitian.

\section{GAMBARAN LOKASI PENELITIAN}

\section{Lokasi dan Wilayah}

Desa Parakan adalah desa yang terletak di Kecamatan Ciomas, Kabupaten Bogor, Provinsi Jawa Barat merupakan daerah padat penduduk dengan luas $238.232 \mathrm{Ha}$ yang sebagian besar penggunaan lahannya adalah untuk sawah yaitu seluas 106.465 Ha. Batas wilayah Desa Parakan, yaitu :

\section{a. Sebelah utara : Desa Mekar Jaya \\ b. Sebelah selatan: Desa Pasar Gurih \\ c. Sebelah timur : Desa Kota Batu \\ d. Sebelah selatan: Desa Pagelaran}

Jarak Desa Parakan dari pusat pemerintahan kecamatan adalah tiga kilo meter yang dapat ditempuh selama 30 menit dengan menggunakan kendaraan bermotor dan dua jam dengan berjalan kaki. Sementara itu jarak Desa Parakan dari ibu kota Kabupaten Bogor adalah $25 \mathrm{~km}$ yang dapat ditempuh selama dua jam dengan menggunakan kendaraan bermotor dan 8 jam dengan berjalan kaki. Jarak Desa Parakan dari ibu kota Provinsi adalah $125 \mathrm{~km}$ yang dapat ditempuh selama 10 jam dengan menggunakan kendaraan bermotor dan 48 jam dengan berjalan kaki.

Dilihat dari kondisi fisik, Desa Parakan memiliki topografi wilayah dataran rendah yang bebas banjir.Desa Parakan terletak $210 \mathrm{mdl}$ dengan curah hujan $208 \mathrm{~mm} / \mathrm{thn}$ dan mempunyai suhu ratarata harian $270 \mathrm{C}$.

\section{Tata Guna Lahan}

Sebagian besar tanah di Desa Parakan merupakan lahan pertanian yang cukup luas walaupun sudah banyak yang dimanfaatkan untuk lahan perumahan/pemukiman. Lahan yang digunakan terluas adalah untuk pertanian sawah berupa sawah irigasi teknis yaitu seluas 106.465 ha lalu 96.617 ha lahan diperuntukan untuk perkebunan.

Luas seluruh lahan di Desa Parakan adalah 238.232 Ha dengan penggunaan lahan untuh sawah dan perkebunan sebesar $203.082 \mathrm{Ha}$ dan sisanya sebesar $35.150 \mathrm{Ha}$ diperuntukan untuk perumahan dan prasarana desa lainnya. Rumah penduduk di Desa Parakan umumnya difungsikan untuk tempat tinggal. Tipe rumah penduduk mayoritas bertipe rumah menengah dengan satu lantai dan kondisi rumah penduduk secara umum dalam kondisi cukup baik.

Tekstur tanah di Desa Parakan umumnya bertekstur pasiran, dengan warna tanah hitam. Keseluruhan tanah di Desa Parakan tingkat erosi tanahnya masuk dalam kategori tidak bererosi. Mayoritas petani di Desa Parakan merupakan petani yang tidak memiliki lahan pertanian. Sementara itu mayoritas petani di Desa Parakan yang memiliki lahan pertanian hanya memiliki lahan yang kurang dari $1 \mathrm{Ha}$. Hal ini memperlihatkan bahwa di desa tersebut sudah terjadi perpencaran lahan pertanian.

\section{Kependudukan dan Mata Pencaharian}

Jumlah penduduk di Desa Parakan sampai Mei 2011 berdasarkan data monografi desa adalah sebanyak 9.252 jiwa, yang terdiri dari 4.905 orang laki-laki dan 4.347 orang perempuan. Jumlah kepala keluarga yang ada di Desa Parakan mencapai $3040 \mathrm{KK}$, yang terdiri dari 2.628 kepala keluarga laki-laki dan 412 kepala keluarga perempuan. Dari Tabel 4.3 dapat dilihat bahwa komposisi penduduk paling banyak terdapat pada klompok umur 0-4 tahun yaitu sebanyak 1157 jiwa (12,50\%). Sedangkan kelompok umur diatas 70 tahun jumlahmya paling sedikit yatu sebanyak 225 jiwa $(2,43 \%)$.

Bila dilihat dari golongan umurnya, terdapat sekitar $24,07 \%$ penduduk yang berada pada golongan umur $0-14$ tahun. Hal ini menunjukan bahwa jumlah anak-anak di Desa Parakan mempunyai proporsi yang cukup besar yang berarti angka kelahiran di Desa Parakan dapat dikatakan cukup tinggi. Penggunaan KB sebagai salah satu alat untuk menekan angka kelahiran masih rendah. Masyarakat Desa Parakan masih mempunyai pandangan bahwa dengan memiliki banyak anak, mereka akan mendapatkan uang yang besar dengan mempekerjakan anak-anak mereka.

Tingkat pendidikan penduduk Desa Parakan sebagian besar adalah tamatan Sekolah Dasar (SD) atau sederajat sebanyak 
846 jiwa atau sekitar 32,97\%. Fasilitas pendidikan yang tersedia di Desa Parakan adalah dua buah SD, dua MI, dua MTs serta satu SMK. Sarana dan prasarana yang tersedia di tiap-tiap sekolah tersebut cukup bagus walaupun masih ada yang mengalami kerusakan. Tidak tersedianya SMP dan SMA menyebabkan masyarakat harus melintasi desa lain atau ke ibu kota kecamatan untuk melanjutkan ke jenjang yang lebih tinggi. Mata pencaharian penduduk Desa Parakan sebagian besar adalah buruh di usaha alas kaki yaitu sebesar $72,42 \%$. Wirausahawan yang bergerak dibidang alas kaki pun mencapai $12,9 \%$. Pekerjaan di industri kecil khususnya industri alas kaki merupakan pekerjaan yang dominan dilakoni sebagian besar masyarakat di Desa Parakan. Setiap RT di Desa Parakan terdapat bengkel sandal baik itu dari skala rumahan hingga skala yang cukup besar dengan pekerja antara 2 hingga 16 orang. Tabel 4.6 berikut memperlihatkan data perusahaan dan industri yang terdapat di Desa Parakan.

Industri sepatu/sandal merupakan industri yang dominan di Desa Parakan, tidak mengherankan lantaran industri ini telah cukup lama berkembang di masyarakat. Bahkan jumlahnya mencapai lebih dari 90 persen dari total keseluruhan usaha yang ada di Desa Parakan. Hal ini menjadikan mayoritas penduduk Desa Parakan menggantungkan hidupnya pada industri ini.

\section{Kelembagaan dan Struktur Pemerintahan Desa}

Terdapat kelembagaan formal serta kelembagaan nonformal di Desa Parakan. Kelembagaan formal yang ada di Desa Parakan terdiri dari lembaga pemerintah desa, LKMD, LPMD, BUMD, PKK, Karang Taruna dan Kelompok Tani. Lembaga non-formal yang ada di Desa Parakan antara lain yaitu kelompok pengajian.

Kelompok Tani yang terdapat di Desa Parakan ada lima, yaitu KT Sugih Mukti, KT Silih Asih, KT Harja, KT Mawar dan KT Mitra Tani. Keseluruhan Kelompok Tani tersebut menjadikan padi sebagai komoditas utamanya. Wilayah administrasi Desa Parakan terbagi atas sembilan RW dan 34 RT. Kepala desa dalam melaksanakan tugasnya dibantu oleh seorang sekertaris desa, delapan orang kepala urusan serta beberapa aparat desa lainnya.

\section{GAMBARAN UMUM INDUSTRI KECIL SANDAL}

Industri kecil sandal memiliki sejarah lahir yang sama dengan industri sepatu di daerah Ciomas lainnya yakni dimulai pada masa penjajahan Belanda (sekitar tahun 1920). Pada tahun 1948, sebuah koperasi yang bernama Persatuan Sepatu Bogor (Persebo) didirikan; keberadaan persatuan ini menunjukkan ada banyak pengrajin sepatu yang beroperasi di atau di sekitar Ciomas pada waktu itu. Para anggota koperasi juga termasuk para pengrajin sepatu yang ada di Kabupaten Bogor. Persebo juga dikenal menghasilkan beberapa orang pengusaha sukses yang kemudian membuka bisnis sepatu di Cibaduyut dan daerah-daerah lain. Banyak di antara mereka yang kembali ke desa-desa mereka dan membuka bengkel sendiri. Beberapa bengkel pembuat sepatu kulit pun dibuka di Desa Parakan. Pada saat produksi meningkat, lebih banyak warga desa meninggalkanlahan pertanian mereka dan terlibat dalam pembuatan sepatu. Lebih mudah diproses dan hanya membutuhkan sedikit ketrampilan dalam membuat sepatu, lebih banyak warga desa yang terjun ke dalam pembuatan sepatu. Lebih banyak bengkel yang mulai bermunculan di Parakan dan desa-desa di sekitarnya, terutama di sepanjang jalan yang menghubungkan Parakan dengan Empang, yang kemudian, hingga saat ini, menjadi pusat perdagangan bahan mentah di kota Bogor (walaupun secara teknis ia hanya sebuah desa yang terletak di pinggiran kota).

Industri sandal di Desa Parakan bisa disebut sebagai industri yang menjadi tulang punggung utama perekonomian di desa ini. Hal ini lantaran hamper disetiap RT. Berdasarkan data yang di dapat dari kantor Desa Parakan, terdapat setidaknya 302 bengkel sandal di desa ini baik yang dari skala kecil hingga skala yang relatif besar.

Bengkel besar di Desa Parakan bisa mempekerjakan 10 hingga 15 pekerja lebih dan mampu menghasilkan 2.000 pasang sepatu setiap minggunya. Bengkel besar ini biasanya menggunakan peralatan produksi yang lebih baik seperti mesin jahit dan mesin pres listrik dan mereka memiliki gudang sendiri. Sebuah bengkel besar biasanya membagikan beban kerjanya dengan bengkel-bengkel yang lebih kecil. Unit-unit yang lebih kecil ini mempekerjakan 5-10 pekerja dan dapat menghasilkan hingga 50-100 kodi (atau 1.000-2.000 pasang sepatu) setiap minggu. Sementara itu untuk bengkel sandal yang berbasis rumahan mempekerjakan tidak lebih dari 5 pekerja dan menghasilkan 30-50 kodi (600-1.000 pasang sepatu) per minggu. Bengkel sandal yang berbasis rumahan menggunakan bagian rumah mereka seperti ruang tamu, teras atau pojok dapur sebagai ruang kerja mereka.

Tempat yang biasa digunakan sebagai proses produksi sandal di Desa Parakan ini umumnya adalah rumah-rumah yang sekaligus juga menjadi tempat tinggal si pemilik usaha bengkel sandal. Industri sandal ini termasuk industri yang sederhana. Bahan baku yang digunakan untuk membuat sepatu umumnya dari bahan spon walaupun ada juga yang menggunakan bahan sejenis karet dan imitasi kulit tapi jumlahnya sangat sedikit. Teknologi yang digunakan pun masih sederhana seperti mesin jahit, kompor, pisau, dan gunting. Alat yang dapat terbilang modern hanya gurinda yang digunakan untuk menghaluskan, itu pun masih sedikit dimiliki oleh bengkel sandal.

Terdapat dua jenis pekerjaan di bengkel sandal dilihat dari proses yang harus dijalani dalam pembuatan sandal, yaitu:

1. Bagian bawah, meliputi sproses memanaskan bagian bawah sandal/sepatu, mengelemnya dan menempelkannya sehingga menjadi sandal/sepatu yang utuh (ngopen). Pekerja yang mengerjakan bagian bawah ini disebut pekerja bawah karena bertugas menyelesaikan bagian bawah sepatu/sandal. Pekerja bawah ini cenderung terkena resiko penyakit yang lebih tinggi dibandingkan pekerja atas karena lama dan kuatnya mereka berinteraksi dengan bahan-bahan kimia seperti lem. Selain itu keadaan bengkel dimana pekerja bawah umumnya mengerjakan pekerjaan mereka juga sempit dan hanya memiliki sedikit ventilasi. Para pekerja ini umumnya berumur lebih muda dibandingkan pekerja atas, karena bagian pekerjaan ini merupakan jenis pekerjaan awal yang dilakukan bila seseorang terjun sebagai pekerja industri sepatu/sandal. Upah yang mereka terima pun umumnya lebih tinggi dari pekerja lain lantaran lamanya waktu yang mereka butuhkan dalam mengerjakan pekerjaan yang ada.

\section{Bagian atas, meliputi proses pengepakan, memasang}


pipa plastik dibagian pengikat jari serta menjiplak pola dasar sepatu atau sandal yang biasa dikenal dengan istilah ngebensol, dan proses penjahitan bagian atas sandal. Adapun pola sandal atau sepatu tersebut dibuat oleh pemilik bengkel sendiri atau berdasarkan permintaan toko yang memasarkan komoditi.

Para pekerja umumnya mulai bekerja dari pukul 7 atau 8 pagi hingga jam 4 atau 5 sore. Mereka beristirahat dengan pulang ke rumah kemudian kembali ke bengkel untuk bekerja lagi setelah jam 7 malam. Hal ini lantaran sistem pengupahan di industri kecil sandal adalah sistem kerja borongan sehingga pekerja berusaha memproduksi sebanyak mungkin sandal/sepatu agar pendapatan mereka bertambah. Dalam sehari umumnya pekerja bisa memproduksi 3-4 kodi sandal/sepatu. Hari Sabtu dan Minggu adalah hari libur bagi pekerja.

Usaha industri sandal ini banyak menyediakan pekerjaan bagi warga desa setempat. Usaha ini mempekerjakan baik pria maupun wanita, dewasa maupun anak-anak. Tenaga yang diserap tidak saja bersasal dari Desa Parakan tapi juga dari desa-desa lainnya. Baik pengusaha maupun buruh sandal rata- rata melibatkan seluruh tenaga kerja rumahtangga mereka lantaran mengejar jumlah produksi yang harus dicapai yang telah ditetapkan oleh toko-toko pemberi order/pesanan. Umumnya yang bekerja di bengkel adalah anak-anak dan orang dewasa laki-laki, sementara pekerja wanita biasa membawa pekerjaannya pulang.

Ada dua musim yang umumnya bengkel-bengkel sepatu mendapat banyak order yakni menjelang lebaran dan awal tahun ajaran baru di sekolah. Pada dua musim ini seluruh bengkel sibuk dan pekerjaan berlangsung dari pagi hingga malam. Pada musim sepi hal sebaliknya terjadi, beberapa bengkel tutup dan buruh-buruhnya mencari pekerjaan lain di sekitar Ciomas atau Jakarta. Buruh tetap atau buruh lepas umumnya direkrut dari kalangan saudara dekat, teman, tetangga terdekat maupun saudara di luar desa. Produk-produk utama yang dihasilkan dari industri sandal di Desa Parakan adalah sandal yang terbuat dari karet busa dan kulit, dan produk-produk ini dijual di toko-toko yang ada di Bogor, Jakarta dan kota-kota di sekitarnya. Tidak ada sepatu dengan disain asli yang dibuat di sini. Sandal dibuat berdasarkan pesanan dan spesifikasi yang diberikan oleh konsumen.

\section{PEKERJA ANAK DALAM INDUSTRI KECIL SANDAL}

\section{Karakteristik Pekerja Anak}

Karakteristik pekerja anak adalah serangkaian aspek-aspek yang terdapat pada diri pekerja anak yang membedakan dia dengan pekerja anak yang lainnya. Karakteristik pekerja anak meliputi jenis kelamin, umur, motivasi bekerja, status bersekolah serta tingkat pendidikan akhir yang ditempuh pekerja anak dan pengalaman kerja pekerja anak itu sendiri.

\section{Jenis Kelamin Pekerja Anak}

Anak-anak yang terlibat masuk ke industri kecil sandal di Desa Parakan tidak hanya laki-laki. Anak-anak perempuan pun juga ada yang bekerja di industri kecil sandal ini. Namun, umumnya pekerja anak yang terdapat di Desa Parakan berjenis kelamin laki-laki. Kondisi ini menunjukan bahwa anak lakilaki di Desa Parakan lah yang diutamakan untuk bekerja dalam industri kecil sandal. Hal ini lantaran adanya anggapan bahwa anak laki-laki kelak yang akan menjadi kepala keluarga dan bertanggungjawab menafkahi keluarganya. Maka dari itu anak laki-laki perlu memiliki pengalaman kerjasejak dini. Sementara itu anak perempuan dianggap lebih pantas di rumah membantu ibunya mengerjakan pekerjaan domestik atau sekedar membantu menjaga adik-adiknya. Pekerjaan di bengkel sandal umumnya cukup berat dan dianggap oleh sebagian besar pemilik bengkel kurang cocok untuk dilakukan oleh perempuan. Selain itu anak perempuan dianggap kurang pantas jika harus bekerja sampai malam seperti yang diharuskan di industri sepatu. Secara umum, karena pemilik usaha biasanya adalah saudara, maka anak perempuan diberi tugas yang lebih ringan.

\section{Umur Pekerja Anak}

Anak-anak yang bekerja di Desa Parakan usianya berkisar antara 11-16 tahun. Rata-rata dari mereka mulai bekerja setelah tamat Sekolah Dasar. Rentang usia 10-14 tahun adalah usia pekerja anak yang mendominasi di Desa Parakan baik untuk laki-laki maupun untuk perempuan. Hal ini menunjukan bahwa pekerja anak di industri kecil sandal Desa Parakan merupakan anak-anak yang masih termasuk dalam usia sekolah. Pada usia yang masih sangat muda mestinya mereka menikmati masa kanak-kanak dengan bermain dan belajar. Kenyataannya adalah mereka berada pada situasi dengan alasan tertentu mengharuskan anak-anak tersebut untuk terjun ke dunia kerja di industri kecil sandal.

\section{Status Bersekolah dan Tingkat Pendidikan Pekerja Anak}

Secara umum, sebagian besar pekerja anak di Desa Parakan sudah tidak bersekolah. Kurangnya minat untuk belajar menjadi sebab utama dari putus sekolahnya mereka. Lebih dari setengah pekerja anak di Desa Parakan telah berstatus putus sekolah. Hal ini menyebabkan mereka memiliki banyak waktu luang yang bisa mereka habiskan untuk bekerja di industri kecil sandal.

Lebih lanjut, pekerja anak tidak hanya telah berstatus putus sekolah tapi juga memiliki pendidikan yang rendah. Mereka berpendidikan rendah dengan kata lain hanya menempuh pendidikan $\leq 6$ tahun yaitu mereka yang tidak tamat SD atau tamat SD namun tidak melanjutkan ke jenjang pendidikan yang lebih tinggi.

Sementara itu hanya sedikit dari pekerja anak yang berpendidikan sedang, yaitu mereka yang menempuh bangku SMP dan SMA. Hanya satu orang responden pekerja anak yang tingkat pendidikannya sampai di bangku SMA, itu pun hanya sampai kelas 1 SMA dan kemudian tidak melanjutkan sekolahnya.

Desa Parakan memiliki sarana pendidikan dari tingkat TK hingga SMK. Sekolah-sekolah yang ada pun dapat dikatakan memiliki fasilitas yang cukup memadai, jumlah pengajar juga telah mencukupi. Adanya dana BOS menjadikan sekolah gratis dari biaya SPP. Walaupun demikian, minat para siswa untuk bersekolah masih sangat rendah.

Rendahnya tingkat pendidikan pekerja anak di Desa Parakan disebabkan lantaran kurangnya kesadaran dari 
para orangtua terhadap pentingnya arti pendidikan bagi anak. Anak-anak kurang dimotivasi untuk bersekolah sehingga mereka malas untuk bersekolah ataupun melanjutkan sekolah setelah lulus.

Faktor lain yang menjadi alasan rendahnya pendidikan pekerja anak adalah adanya anggapan bahwa tingkat pendidikan yang tinggi tidak menjamin bagi seseorang untuk mendapatkan pekerjaan yang layak serta uang yang banyak. Alasan lain yang menyebabkan rendahnya pendidikan pekerja anak adalah faktor biaya, orangtua berpenghasilan rendah sehingga kurang mampu untuk membiayai anak-anak mereka ke jenjang yang lebih tinggi.

Pekerja anak baik yang masih sekolah maupun sudah putus sekolah memiliki waktu untuk bekerja. Anak-anak yang putus sekolah atau tidak melanjutkan sekolah mempunyai waktu full time untuk bekerja di bengkel sandal. Sementara itu anak-anak yang masih bersekolah bekerja paruh waktu atau disesuaikan dengan waktu sekolah mereka.

\section{Motivasi Bekerja Pekerja Anak}

Motivasi adalah alasan yang melatarbelakangi pekerja anak untuk bekerja di industri kecil sandal. Tiap pekerja anak memiliki alasan yang berbeda-beda untuk bekerja menjadi buruh sandal di industri kecil sandal. Umumnya pekerja anak termotivasi untuk bekerja dengan alasan yang berasal dari keinginan sendiri untuk hidup mandiri dan keinginan untuk dapat menghasilkan uang sendiri. Kondisi lingkungan pun mendukung dengan banyaknya terdapat kesempatan kerja untuk mereka dapat terlibat.

Kuatnya dorongan dari keinginan anak itu sendiri untuk bekerja agar bisa mandiri dan menghasilkan uang menunjukan motivasi kerja mereka yang tinggi. Faktor lingkungan pun berpengaruh terhadap kuatnya keinginan mereka ini. Industri kecil sandal yang memang menjadi andalan di Desa Parakan dengan bengkel sandal yang banyak terdapat hampir disetiap RT menyebabkan banyaknya peluang kerja sebagai buruh di bengkel-bengkel sandal tersebut. Hal ini kemudian ditambah status putus sekolah anak-anak tersebut yang menyebabkan mereka memiliki banyak waktu kosong sehingga mereka memilih bekerja di industri sandal daripada tidak ada kegiatan apaapa.

Orangtua pun tidak melarang anaknya bekerja karena mereka memandang positif terhadap bekerjanya anak mereka di industri sandal. Orangtua menganggap bahwa lebih baik anak mereka bekerja daripada menganggur di rumah. Bekerjanya anak selain membawa nilai ekonomi karena anak akan menghasilkan uang sendiri juga ada proses pembelajaran. Melalui bekerja anak-anak dapat belajar untuk hidup lebih mandiri.

\section{Pengalaman Kerja Pekerja Anak}

Tiap pekerja anak memiliki pengalaman kerja yang berbeda-beda. Pengalaman kerja mereka dapat dilihat melalui seberapa lama mereka telah bekerja di industri kecil sandal tersebut. Mayoritas pekerja anak memiliki pengalaman kerja yang rendah atau telah bekerja di bengkel sandal kurang dari satu tahun. Hanya sedikit dari pekerja anak yang pengalaman kerjanya telah lebih dari tiga tahun.

Hal ini menunjukan bahwa pekerja anak di industri kecil sandal Desa Parakan umumnya masih belum memiliki banyak pengalaman karena kebanyakan dari mereka baru bekerja selama beberapa bulan. Biasanya pekerja anak yang telah bekerja lebih dari 1 tahun adalah pekerja anak yang bekerja penuh (full time) dan biasanya sudah putus sekolah. Mereka yang bekerja kurang dari satu tahun atau yang termasuk baru di industri ini biasanya adalah anakanak yang masih bersekolah dan masih bekerja setengah hari (part time).

\section{Karakteristik Rumahtangga Pekerja Anak}

Karakteristik rumahtangga pekerja anak adalah serangkaian aspek-aspek yang terdapat pada rumahtangga pekerja anak yang membedakan rumahtangganya dengan rumahtangga pekerja anak yang lainnya. Karakteristik rumahtangga pekerja anak dalam hal ini dapat dilihat dari status sosial ekonomi. Status sosial ekonomi rumahtangga dalam hal ini dapat dilihat melalui beban tanggungan rumahtangga, pekerjaan dan tingkat pendidikan kepala rumahtangga serta tingkat pendapatan rumahtangga.

\section{Beban Tanggungan Rumahtangga Pekerja Anak}

Beban tanggungan yang dimaksud dalam penelitian ini adalah anggota-anggota keluarga yang ditanggung hidupnya oleh kepala rumahtangga. Rumahtangga pekerja anak umumnya dikepalai oleh seorang laki-laki dan hanya sedikit kepala rumahtangga yang berjenis kelamin perempuan. Mereka, para kepala rumahtangga perempuan umumnya adalah single parent sehingga mereka harus menggantikan posisi laki-laki dan turut serta berperan mencari nafkah bagi anggota-anggota rumahtangganya. Para kepala rumahtangga ini adalah pencari nafkah utama dalam keluarga. Mereka berperan dalam mencukupi kebutuhan anggota-anggota rumahtangganya baik yang sudah bekerja maupun yang belum bekerja. Anggotaanggota rumahtangga yang kehidupannya ditanggung oleh kepala rumahtangga ini kemudian disebut sebagai beban tanggungan rumahtangga.

Umumnya rumahtangga pekerja anak di Desa Parakan merupakan rumahtangga dengan beban tanggungan yang rendah atau hanya terdapat $\leq$ empat orang yang menjadi beban tanggungan dalam rumahtangga tersebut. Hal ini menunjukan bahwa beban tanggungan rumahtangga yang tinggi tidak menjamin timbulnya pekerja anak. Anak-anak yang berasal dari rumahtangga yang masuk kategori memiliki beban tanggungan rumahtangga yang rendah pun berpeluang besar untuk turut serta bekerja mencari tambahan uang di industri kecil sandal.

\section{Pekerjaan dan Tingkat Pendidikan Kepala Rumahtangga}

Seperti yang telah diutarakan pada bab sebelumnya, pekerjaan di industri sandal merupakan pekerjaan mayoritas yang dilakoni oleh masyarakat di Desa Parakan. Rata-rata pekerja anak yang bekerja sebagai buruh di industri kecil sandal pun juga berasal dari rumahtangga yang dikepalai oleh mereka yang juga bekerja di industri ini. Hal ini untuk selanjutnya dapat dilihat pada Tabel 6.9 berikut.

Berdasarkan Tabel 2 dapat terlihat bahwa mayoritas kepala rumahtangga pekerja anak di Desa Parakan bekerja sebagai buruh di bengkel sandal. Kepala rumahtangga yang bekerja sebagai buruh di industri kecil sandal cenderung 
meningkatkan jumlah tenaga kerja anak. Buruh yang bekerja di industri sandal ini seringkali membawa serta pekerjaan mereka untuk dikerjakan di rumah. Saat itulah anak-anak secara tidak langsung disosialisasikan dengan pekerjaan sebagai buruh sandal. Seringkali orangtua meminta bantuan anaknya untuk turut serta membantu mengerjakan pekerjaannya itu sehingga si anak mulai mempelajari cara-cara membuat sepatu.

Tabel 2. Jumlah dan Persentase Rumahtangga Pekerja Anak Berdasarkan Pekerjaan Kepala Rumahtangga, Desa Parakan, Kec. Ciomas, Kab. Bogor, 2011

\begin{tabular}{lrr}
\hline Jenis Pekerjaan & $\mathrm{N}$ & $\%$ \\
\hline Buruh di bengkel sandal & 24 & 77.4 \\
Petani & 1 & 3.3 \\
Pedagang & 3 & 9.7 \\
PNS & 0 & 0 \\
Jasa & 3 & 9.7 \\
Jumlah & 31 & 100 \\
\hline
\end{tabular}

Industri kecil sandal di desa ini keberadaannya menjadi tulang punggung bagi sebagian besar masyarakat setempat. Sebagai industri kecil, pekerja di bengkel sandal tidak diharuskan memiliki tingkat pendidikan yang tinggi sehingga mereka yang berpendidikan minim pun dapat dengan mudah bekerja di sektor ini. Seperti yang telah diperlihatkan sebelumnya bahwa mayoritas pekerja anak di Desa Parakan berpendidikan rendah atau tidak tamat SD. Umumnya kepala rumahtangga pekerja anak berpendidikan rendah. Hal ini berhubungan pula dengan pekerjaan mereka yang umumnya hanyalah buruh di bengkel sandal, karena di bengkel sandal tersebut tidak mensyaratkan buruh dengan pendidikan yang tinggi. Selanjutnya pada Tabel 3 berikut akan digambarkan hubungan antara tingkat pendidikan kepala rumahtangga pekerja anak dengan tingkat pendidikan anak itu sendiri.

Tabel 3. Jumlah dan Persentase Rumahtangga Pekerja Anak Berdasarkan Tingkat Pendidikan Kepala Rumahtangga dan Tingkat Pendidikan Pekerja Anak, Desa Parakan, Kecamatan Ciomas, Kabupaten Bogor, 2011

\begin{tabular}{|c|c|c|c|c|c|c|}
\hline & & & \multicolumn{3}{|c|}{$\begin{array}{l}\text { Tingkat Pendidikan } \\
\text { Kepala Rumahtangga }\end{array}$} & \multirow[t]{2}{*}{ Jumlah } \\
\hline & & & Rendah & Sedang & Tinggi & \\
\hline \multirow{8}{*}{ 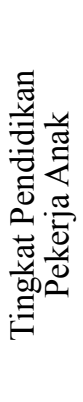 } & Rendah & $\mathrm{N}$ & 11 & 5 & 0 & 16 \\
\hline & & $\%$ & 42.3 & 19.2 & 0 & 61.5 \\
\hline & Sedang & $\mathrm{N}$ & 6 & 4 & 0 & 10 \\
\hline & & $\%$ & 23.1 & 15.4 & 0 & 38.5 \\
\hline & Tinggi & $\mathrm{N}$ & 0 & 0 & 0 & 0 \\
\hline & & $\%$ & 0 & 0 & 0 & 0 \\
\hline & Jumlah & $\mathrm{N}$ & 17 & 8 & 0 & 26 \\
\hline & & $\%$ & 100 & 100 & 1 & 100 \\
\hline
\end{tabular}

Berdasarkan Tabel 3 terlihat bahwa terdapat hubungan antara tingkat pendidikan kepala rumahtangg dengan tingkat pendidikan pekerja anak. Makin tinggi tingkat pendidikan kepala rumahtangga maka makin tinggi pula tingkat pendidikan pekerja anak. Kepala rumahtangga yang berpendidikan rendah akan cenderung kurang memotivasi anak-anak mereka bersekolah karena anggapan bahwa pendidikan yang tinggi tidak menjamin seseorang mendapatkan pendidikan yang layak.

Rumahtangga yang dikepalai oleh orang dengan tingkat pendidikan yang lebih tinggi cenderung untuk menyekolahkan anak mereka dibandingkan dengan rumahtangga yang dikepalai oleh orang dengan tingkat pendidikan rendah. Setidaknya ada dua penjelasan untuk ini. Pertama, kepala rumahtangga dengan tingkat pendidikan yang lebih tinggi dapat menghasilkan pendapatan yang lebih tinggi untuk keluarga mereka. Sehingga tidak perlu bagi mereka untuk menyuruh anak mereka bekerja. Kedua, orangtua yang berpendidikan tinggi memiliki pemahaman yang lebih baik tentang pentingnya manfaat pendidikan dari pengalaman pribadi mereka.

\section{Tingkat Pendapatan Rumahtangga}

Tingkat pendapatan rumahtangga pekerja anak dihitung dengan pendekatan pengeluaran yang penentuannya dilakukan atas informasi dari pejabat kelurahan setempat mengenai kondisi sosial ekonomi masyarakat di Desa Parakan serta survey langsung dengan keluarga responden. Penggunaan pendekatan pengeluaran untuk mengukur tingkat pendapatan rumahtangga pekerja anak dilakukan lantaran kepala rumahtangga pekerja anak mayoritas bekerja di industri kecil sandal yang sifatnya musiman. Hal ini berarti bahwa pendapatan mereka tidak tetap per bulannya sehingga akan lebih mudah mengukurnya melalui pendekatan pengeluaran. Rumahtangga pekerja anak kebanyakan berada pada kategori tingkat pendapatan rendah atau berpengeluaran kurang dari $\mathrm{Rp} 600.000,00$ per bulan yaitu sebanyak 54,8 persen. Sementara itu rumahtangga pekerja anak yang berada pada kategori tingkat pendapatan sedang atau memiliki pengeluaran antara Rp 600.000,00 - Rp 1.200.000,00 per bulan ada sebanyak 45,2 persen. Lebih lanjut tidak ditemui adanya rumahtangga pekerja anak yang berada pada kategori tingkat pendapatan tinggi atau memiliki pengeluaran lebih dari Rp 1.200.000,00 per bulan.

Berdasarkan Tabel 4, pekerja anak yang berasal dari rumahtangga yang tingkat pendapatannya rendah lebih banyak yang bekerja karena dorongan orangtua yaitu sebesar 16,1 persen dan sisanya 19,4 persen bekerja karena diajak teman/kerabat serta 19,4 persen yang bekerja karena keinginan sendiri. Sementara itu pekerja anak yang berasal dari rumahtangga yang tingkat pendapatannya sedang lebih banyak dari mereka yang bekerja dengan alasan ingin mandiri yaitu sebanyak 6,5 persen. Hanya 12,9 persen pekerja anak yang berasal dari rumahtangga dengan tingkat pendapatan sedang yang bekerja karena dorongan orangtua dan sisanya 25,8 persen bekerja karena diajak teman/kerabat.

Terlihat bahwa pada rumahtangga yang tingkat pendapatannya rendah, orang tua lebih mendorong anaknya untuk bekerja mencari nafkah. Desakan ekonomi memaksa orangtua pekerja anak untuk mendorong anaknya ke pangsa pasar kerja di industri kecil sandal. Sementara itu pada rumahtangga yang lebih berkecukupan, anak-anak 
memilih bekerja di industri kecil sandal atas keinginan sendiri lantaran ingin menghasilkan uang sendiri dan belajar mandiri.

Tabel 4. Jumlah dan Persentase Rumahtangga Pekerja Anak Berdasarkan Tingkat Pendapatan Kepala Rumahtangga dan Motivasi Bekerja Pekerja Anak, Desa Parakan, Kecamatan Ciomas, Kabupaten Bogor, 2011

\begin{tabular}{|c|c|c|c|c|c|c|}
\hline & & & \multicolumn{3}{|c|}{ Motivasi } & \multirow[b]{2}{*}{$\begin{array}{l}\text { Jum- } \\
\text { lah }\end{array}$} \\
\hline & & & $\begin{array}{l}\text { D or on - } \\
\text { g a n } \\
\text { orangtua }\end{array}$ & $\begin{array}{l}\text { Diajak } \\
\text { teman. }\end{array}$ & Tinggi & \\
\hline \multirow{8}{*}{ 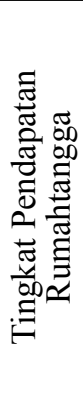 } & Rendah & $\mathrm{N}$ & 5 & 6 & 6 & 17 \\
\hline & & $\%$ & 16.1 & 19.2 & 19.4 & 100 \\
\hline & Sedang & $\mathrm{N}$ & 2 & 4 & 8 & 14 \\
\hline & & $\%$ & 6.5 & 12.9 & 25.8 & 100 \\
\hline & Tinggi & $\mathrm{N}$ & 0 & 0 & 0 & 0 \\
\hline & & $\%$ & 0 & 0 & 0 & 0 \\
\hline & Jumlah & $\mathrm{N}$ & 7 & 10 & 14 & 31 \\
\hline & & $\%$ & 22.6 & 32.3 & 45.2 & 100 \\
\hline
\end{tabular}

\section{Karakteristik Pekerjaan Pekerja Anak}

Karakteristik pekerjaan adalah serangkaian aspek-aspek yang terdapat pada pekerjaan pekerja anak di industri kecil sandal yang membedakan satu pekerjaan dengan pekerjaan yang lainnya. Karakteristik pekerjaan meliputi jenis pekerjaan, jumlah jam kerja, status kerja dan sistem pengupahan.

\section{Jenis Pekerjaan Pekerja Anak di Industri Sandal}

Sebagaimana yang telah dijelaskan, pekerjaan di industri kecil sandal terbagi menjadi dua jenis pekerjaan, yaitu bagian atas dan bagian bawah. Tingkat kesulitan antara kedua jenis pekerjaan tersebut tidak jauh berbeda sehingga pembagian kerja kedua jenis pekerjaan tersebut tidak berdasarkan umur pekerja. Mereka, baik yang dewasa maupun anak-anak sama-sama bisa mengerjakannya tergantung pada keterampilan dan kemampuan yang dimiliki pekerja.

\section{Jam Kerja Pekerja Anak}

Pekerja anak memiliki karakteristik individu masingmasing dimana ada pekerja anak yang masih bersekolah dan ada pula pekerja anak yang telah putus sekolah. Perbedaan karakteristik individu ini menyebabkan jam kerja mereka berbeda-beda pula. Pekerja anak yang masih bersekolah umumnya bekerja paruh waktu karena pada pagi harinya mereka harus sekolah. Sementara itu pekerja anak yang putus sekolah memiliki waktu penuh untuk bekerja dari pagi hingga sore, bahkan malam. Umumnya pekerja anak memiliki jam kerja yang tinggi atau mencapai lebih dari 40 jam per minggunya pekerja anak bekerja sebagaimana pekerja dewasa lainnya yaitu selama 8-9 jam mulai dari pukul 08.00-16.00 dengan waktu istirahat pada pukul 12.00-13.00. Terkadang para pekerja anak ini lembur hingga larut malam sampai pukul 23.00 dengan waktu istirahat pada pukul 17.30-19.00. maka, tak jarang bagi pekerja anak yang ikut kerja memiliki jam kerja mencapai 12-13 jam sehari. Walaupun demikian waktu kerja yang umum berlaku di bengkel sandal adalah sehari penuh dan setengah hari. Hal ini lantaran waktu lembur di bengkel sandal jarang sekali ada, kecuali bila bengkel tersebut mendapat pesanan dalam jumlah yang banyak.

\section{Status Kerja Pekerja Anak}

Terdapat tiga status kerja dari pekerja anak yang dapat di jumpai di bengkel sandal Desa Parakan, yaitu:

a. Pekerja keluarga, yaitu anak-anak yang bekerja pada orangtua mereka yang memiliki bengkel sandal atau sekedar membantu orangtua mereka bekerja menyelesaikan pekerjaannya.

b. Pekerja magang atau kenek, yaitu mereka yang umumnya belum begittu lancer dan cepat dalam membuat sandal dan mereka ingin menjadi pekerja tetap di industri ini melalui usaha menambah pengalaman yang didapat melalui proses belajar sambil bekerja.

c. Pekerja tetap, yaitu mereka yang kemampuan dan keterampilannya sudah dianggap baik oleh pengusaha sandal.

\section{Sistem Pengupahan di Industri Sandal}

Sistem pengupahan yang umumnya berlaku di industri kecil sandal adalah sistem borongan. Upah yang diberikan oleh pengusaha industri sandal dengan sistem borongan ini didasarkan pada jumlah yang dihasilkan oleh pekerja dengan memperhatikan pekerjaannnya masing-masing. Upah dibayarkan tiap minggunya pada hari terakhir kerja dalam seminggu. Berikut tingkat pendapatan pekerja anak yang disajikan pada Tabel 5 .

Tabel 5. Jumlah dan Persentase Pekerja Anak Berdasarkan Tingkat Pendapatan, Desa Parakan, Kecamatan Ciomas, Kabupaten Bogor, 2011

\begin{tabular}{lrr}
\hline Tingkat Pendapatan & N & $\%$ \\
\hline Rendah & 15 & 48.4 \\
Sedang & 12 & 38.7 \\
Tinggi & 4 & 12.9 \\
Jumlah & 31 & 100 \\
\hline
\end{tabular}

Pada Tabel 5 diketahui bahwa, sebanyak 48,4 persen pekerja anak berpendapatan rendah atau kurang dari Rp $60.000,00$ per minggu. Sementara itu pekerja anak yang memiliki pendapatan sedang dengan total pendapatan perminggunya mencapai Rp60.000,00-Rp120.000,00 ada sebanyak 38,7 persen. Pekerja anak dengan pendapatan tinggi, yaitu lebih dari Rp $120.000,00$ per minggunya hanya berjumlah sebanyak 12,9 persen. Pendapatan yang diperoleh pekerja anak berhubungan dengan status kerja mereka di bengkel sandal. Tabel 6 di bawah ini menunjukan hubungan antara status kerja pekerja anak dengan tingkat pendapatan mereka.

Upah yang diterima oleh pekerja anak dari hasil kerja mereka dengan sistem borongan masih sangat rendah. Ditemukan pula terdapat hubungan antara upah yang diterima pekerja anak dengan status kerja mereka di bengkel sandal. Pekerja anak yang berstatus sebagai 
pekerja keluarga umumnya berpenghasilan rendah karena mereka biasanya bekerja hanya sekadar untuk membantu orangtua.

Hal ini menyebabkan upah yang mereka terima biasanya hanya berupa uang jajan dari orangtua mereka yang jumlahnya sekitar Rp10.000,00 hingga Rp20.000,00. Selanjutnya, pekerja anak yang berstatus sebagai pekerja magang berpendapatan lebih tinggi dari pekerja anak. Walaupun demikian mereka masih termasuk dalam kategori berpendapatan rendah. Hal ini karena mereka yang masih status sebagai pekerja magang yang mana umumnya adalah pemula di industri ini sehingga hanya mampu menghasilkan sepatu/sandal dalam jumlah kodi yang sedikit.

Pekerja anak yang sudah berstatus sebagai pekerja tetap di bengkel sandal memiliki pendapatan paling tinggi diantara pekerja keluarga dan pekerja magang. Pekerja anak yang merupakan pekerja tetap biasanya telah terampil dan ahli. Mereka dapat membuat sepatu/sandal dalam jumlah kodi yang lebih banyak tiap minggunya dibanding mereka yang masih berstatus sebagai pekerja magang.

\section{Faktor-Faktor yang Mendorong Munculnya Pekerja Anak}

Merujuk pada hasil yang didapat dari karakteristik pekerja anak, karakteristik rumahtangga pekerja anak serta karakteristik pekerjaan dapat dianalisis beberapa faktor-faktor yang mempengaruhi masuknya anak untuk bekerja di industri sandal. Faktor pertama yang berperan dalam memicu masuknya pekerja anak ke lapangan kerja dilihat dari karakteristik pekerja anak itu sendiri adalah faktor pendidikan.

Fakta di lapangan menunjukan bahwa mayoritas pekerja anak di Desa Parakan sudah tidak bersekolah lagi ditambah lagi tingkat pendidikan para pekerja anak umumnya rendah. Putus sekolahnya anak-anak ini menyebabkan mereka memiliki alternatif yang lebih besar untuk menghabiskan waktu luang mereka dengan bekerja ketimbang membuangbuang waktu di rumah. Pekerja anak yang sudah tidak bersekolah lagi juga lebih memilih bekerja karena dapat menghasilkan uang sendiri.

Faktor kedua yang turut berpengaruh dalam munculnya pekerja anak ditinjau dari karakteristik rumahtangga pekerja adalah adanya sosialisasi baik secara langsung maupun tidak langsung terhadap pekerjaan di bengkel sandal. Fakta di lapangan menunjukan bahwa sebagian besar orangtua pekerja anak tak lain juga merupakan pekerja di bengkel sandal. Banyak dari para orangtua pekerja anak yang umumnya merupakan pengrajin sandal ini mengharapkan anaknya dapat meneruskan pekerjaannya sebagai pengrajin sandal.

Hal ini menyebabkan sebagian besar anak-anak di Desa Parakan umumnya sudah mengenal pekerjaan membuat sandal sejak kecil. Ditambah lagi dengan bengkel-bengkel sandal yang terdapat di setiap RT dan hampir disetiap rumah warga. Hal ini menyebabkan sebagian besar anakanak di Desa Parakan umumnya sudah mengenal pekerjaan membuat sandal sejak kecil. Ditambah lagi dengan bengkel-bengkel sandal yang terdapat di setiap RT dan hampir disetiap rumah warga.
Faktor ketiga bila dilihat dari karakteristik pekerjaan adalah tersedianya lapangan kerja untuk anak-anak dengan pendidikan mereka yang rendah. Bengkel sandal sebagai salah satu industri kecil yang tidak mensyaratkan pendidikan yang tinggi bagi mereka yang ingin masuk di dalamnya. Hal ini memudahkan pekerja anak yang mayoritas masih berpendidikan rendah dan bahkan telah putus sekolah untuk dapat bekerja di bengkel sandal. Selain itu, industri sandal ini bengkel sandal ini tidak tersentuh oleh peraturan pemerintah dalam hal mempekerjakan anak di bawah umur sehingga anak-anak di bawah umur dapat dengan mudah terserap tenaga kerjanya di sektor ini.

\section{PERANAN PEKERJA ANAK TERHADAP RUMAHTANGGA DAN KESEJAHTERAAN DIRINYA}

\section{Peranan Pekerja Anak Terhadap Pendapatan Rumahtangga}

Tiap anggota rumahtangga yang bekerja baik secara langsung maupun tidak langsung berperan terhadap pedapatan rumahtangganya. Hal ini juga berlaku bagi anak-anak yang bekerja di industri kecil sandal. Rata-rata pengalokasian pengeluaran dari upah yang diperoleh pekerja anak adalah untuk keperluan pribadi pekerja anak itu sendiri. Keperluan pribadi tersebut bisa berupa membeli pulsa, uang jajan untuk mereka sendiri saat akhir pekan, atau terkadang untuk arisan, beli pulsa dan ada juga yang menggunakannya untuk ditabung. Kemudian pengalokasian pengeluaran terbesar selanjutnya adalah untuk diberikan kepada orangtua. Pekerja anak memberikan uang kepada orangtua mereka biasanya untuk membantu keperluan belanja membeli makanan bagi kebutuhan rumahtangga itu sendiri. Selain itu ada pula pekerja anak yang turut mengalokasikan upahnya untuk keperluan adik-adiknya. Biasanya mereka turut memberi uang jajan kepada adik-adik mereka.

Tabel 7. Jumlah dan Persentase Pekerja Anak Berdasarkan Penggunaan Upah yang Diterima, Desa Parakan, Kecamatan Ciomas, Kabupaten Bogor, 2011

\begin{tabular}{lrr}
\hline & $\mathrm{N}$ & $\%$ \\
\hline Setiap minggu & 5 & 16.1 \\
2-3 kali sebulan & 5 & 16.1 \\
1 kali sebulan & 12 & 38.7 \\
Tidak pernah & 9 & 29.0 \\
\hline
\end{tabular}

Pada Tabel 7, terlihat bahwa kebanyakan pekerja anak (38,7 persen) jarang memberikan seluruh atau sebagian penghasilan mereka kepada orangtua. Sementara itu pekerja anak yang tiap minggunya menyumbangkan penghasilannya kepada kepala rumahtangga ada sebanyak 16,1 persen, begitu pula halnya pekerja anak yang memberikan penghasilan kepada kepala rumahtangga setidaknya 2-3 kali sebulan ada sebanyak 16,1 persen. Pekerja anak yang tidak pernah memberikan penghasilannya kepada orangtua ada sebanyak 29,0 persen.

Peranan pekerja anak terhadap pendapatan rumahtangga mereka dapat dikatakan masih sangat rendah. Hal ini salah satunya disebabkan oleh pengahasilan yang mereka peroleh per bulannya juga masih dalam katagori yang rendah. 
Uang yang mereka peroleh pun biasanya mereka gunakan untuk keperluan mereka sendiri, dan hanya sesekali mereka berikan kepada kepala rumahtangga. Itupun dalam jumlah yang tidak seberapa. Biasanya mereka memberikan sekitar Rp 20.000,00 hingga Rp 40.000,00.

\section{Dampak Bekerja Anak Terhadap Pendidikan Anak}

Bekerja di industri sandal menyita cukup banyak waktu pekerja anak pada hari kerja (senin-jumat) dan hanya pada hari libur lah (sabtu-minggu) pekerja anak mendapatkan waktu luang untuk melakukan hal lain selain kerja. Hal ini menyebabkan pekerja anak yang mayoritas telah putus sekolah tidak punya waktu untuk memikirkan pendidikan mereka. Pada waktu senggang mereka lebih senang menghabiskan waktu dengan bermain atau jalan-jalan.

Para pekerja anak yang telah putus sekolah ini tidak memiliki motivasi untuk kembali bersekolah, justru mereka ingin meneruskan bekerja di bengkel sandal. Kondisi lingkungan yang sedemikian rupa dimana bekerja di bengkel sepatu merupakan hal yang mudah lantaran tidak dibutuhkannya persyaratan berupa pendidikan tinggi menyebabkan mereka memilih bekerja dibanding bersekolah.

\section{Dampak Bekerja Anak Terhadap Kesehatan Anak}

Bekerja di industri kecil sandal merupakan pekerjaan yang cukup rawan bagi anak-anak yang masih di bawah umur. Kondisi bengkel yang sedemikian rupa dapat berpengaruh terhadap kesehatan diri anak yang bekerja. Berikut kondisi yang terdapat di bengkel sandal yang dinilai oleh pekerja tersaji dalam Tabel 8 .

Tabel 8. Jumlah dan Persentase Pekerja Anak Berdasarkan Kondisi yang Ada di Bengkel Sandal Tempat Mereka Bekerja, Desa Parakan, Kecamatan Ciomas, Kabupaten Bogor, 2011

\begin{tabular}{lrr}
\hline Kondisi di bengkel sandal & $\mathrm{N}$ & $\%$ \\
\hline Debu, uap & 10 & 31.3 \\
Api, gas & 7 & 21.9 \\
Suara bising atau getaran & 4 & 12.5 \\
Dingin atau panas yang ekstrem & 0 & 0 \\
Benda berbahaya (contoh:pisau, dll) & 1 & 3.1 \\
Bekerja di bawah tanah & 0 & 0 \\
Bekerja di ketinggian & 0 & 0 \\
Bekerja di air/danau/kolam/sungai/ & 0 & 0 \\
laut. & & \\
Tempat kerja yang terlalu gelap/tertu- & 4 & 12.5 \\
tup & & \\
Ventilasi yang kurang & 20 & 62.5 \\
Bahan kimia (pestisida,lem, dll) & 9 & 28.1 \\
Bahan peledak & 0 & 0 \\
\hline
\end{tabular}

Berdasarkan pada Tabel 8 , kondisi bengkel sandal yang oleh kebanyakan pekerja anak (62,5 persen) dinilai terdapat pada bengkel tempat mereka bekerja adalah kurangnya ventilasi udara yang ada di tempat kerja. Kondisi yang umum terdapat di bengkel sandal selanjutnya yang dijawab oleh 31,3 persen pekerja anak adalah adanya debu dan uap. Selanjutnya 28,1 persen pekerja anak menjawab bahwa di tempat kerja mereka terdapat bahan kimia seperti pestisida, lem, dan lain-lain, 21,9 persen pekerja anak menjawab bahwa di bengkel sandal tempat mereka bekerja terdapat api dan gas, kemudian 12,5 persen pekerja anak menilai bahwa tempat kerja mereka terlalu gelap/tertutup serta ada suara bising atau getaran di tempat kerja. terdapat 3,1 persen pekerja anak yang menilai bahwa mereka bekerja terdapat benda tajam seperti pisau, dan lain-lain

Pekerja anak terancam bahaya bahan kimia dari lem dan pelarut yang dipakai dalam pembuatan sepatu di tempat mereka bekerja. Bensin yang dipakai sebagai pengencer juga berbahaya bagi kesehatan mereka. Berdasarkan pengamatan di lapangan tempat duduk mereka juga tidak ergonomis karena harus bersila ketika membuat pola atau memotong bahan. Meskipun mereka bisa beristirahat dan menggerakkan badan, namun mereka harus bekerja dalam posisi yang tidak sehat ini selama berjam-jam. Kondisi bengkel sandal yang sedemikian rupa tentunya dapat menimbulkan berbagai masalah kesehatan bagi pekerja anak. Berbagai masalah kesehatan yang dialami oleh pekerja anak tersaji dalam Tabel 9 berikut.

Tabel 9 Jumlah dan Persentase Pekerja Anak Berdasarkan Masalah Kesehatan yang Dialami Akibat bekerja, Desa Parakan, Kecamatan Ciomas, Kabupaten Bogor, 2011

\begin{tabular}{lrr}
\hline Masalah Kesehatan & N & \multicolumn{2}{c}{$\%$} \\
\hline Luka ringan/luka terbuka & 10 & 33.3 \\
Retak tulang & 0 & 0 \\
Keseleo & 2 & 6.3 \\
Terbakar, luka terkena karat, terkena cairan & 2 & 6.3 \\
panas & & \\
Masalah pernafasan & 3 & 9.4 \\
Masalah penglihatan & 0 & 0 \\
Masalah kulit & 0 & 0 \\
Masalah pencernaan/diare & 2 & 6.3 \\
Demam & 8 & 25 \\
Kelelahan yang sangat & 10 & 31.4 \\
\hline
\end{tabular}

Berdasakan Tabel 9 di atas, masalah kesehatan paling banyak yang dialami oleh pekerja anak sebagai akibat dari bekerjanya mereka di industri sandal adalah luka ringan atau luka terbuka yaitu sebanyak 33,3 persen. Luka ringan atau luka terbuka yang terjadi pada pekerja anak umumnya lantaran mereka menjahit bagian atas sepatu. Walaupun demikian, pekerja anak telah menganggap hal ini adalah hal yang biasa dan wajar terjadi. Masalah kesehatan lainnya adalah kelelahan yang sangat yaitu sebesar 31,4 persen. Kelelahan ini terjadi karena anak-anak terkadang ikut lembur hingga larut malam. Demam juga dialami oleh 25 persen pekerja anak, 6,3 persen pekerja anak mengalami masalah pernafasan, dan masing-masing 6,3 persen pekerja anak mengalami keseleo, masalah pencernaan/diare serta luka terbakar, luka terkena karat dan terkena cairan panas.

\section{Dampak Bekerja Anak terhadap Emosional Anak}

Bekerja di bengkel sepatu bersama dengan orang dewasa 
lainnya menimbulkan dampak secara emosional pada diri sang anak. Dampak ini salah satunya dapat timbul dari perlakuan yang diterima oleh pekerja anak di tempat kerja. perlakuan-perlakuan yang diterima pekerja anak di industri kecil sandal tersaji dalam Tabel 10 berikut.

Tabel 10. Jumlah dan Persentase Pekerja Anak Berdasarkan Perlakuan yang Diterima di $\mathrm{T}$ e $\mathrm{m}$ p a $\mathrm{t}$ Kerja, Desa Parakan, Kecamatan Ciomas, Kabupaten Bogor, 2011

\begin{tabular}{lrr}
\hline Perlakuan yang diterima & $\mathrm{N}$ & \multicolumn{2}{c}{$\%$} \\
\hline Diteriaki/dibentak & 10 & 33.3 \\
Dihina & 0 & 0 \\
Dipukul/mengalami tindak kekerasan fisik & 2 & 6.3 \\
Kekerasan fisik & 2 & 6.3 \\
Pelecehan seksual & 3 & 9.4 \\
Dll & 0 & 0 \\
\hline
\end{tabular}

Pada Tabel 10 di atas, terlihat bahwa perlakuan yang umumnya didapat oleh pekerja anak (sebanyak 40,6 persen) adalah diteriaki/dibentak. Pekerja anak sering diteriaki atau dibentak biasanya karena mereka melakukan kesalahan saat bekerja. Perlakuan lainnya, yaitu dihina didapat oleh 12,5 persen pekerja anak, serta dipukul/ mengalami tindak kekerasan fisikdialami oleh 3,1 persen pekerja anan. Sebanyak 6,3 persen pekerja anak mendapat perlakuan seperti sering disuruh-suruh dan dimarahi.

Pekerja anak yang bekerja di tempat tetangga juga diperbolehkan membawa pekerjaan ke rumah, yang lebih nyaman daripada dikerjakan di tempat yang sempit. Anakanak ini bekerja sendirian atau ditemani oleh saudara atau orangtua. Bekerjanya anak-anak bersama orang dewasa lainnya menjadikan diri mereka menjadi lebih dewasa karena seringnya bergaul dengan orang dewasa. Tidak jarang dijumpai pekerja anak yang telah merokok.

Keterlibatan anak-anak dalam bekerja tidak hanya berpengaruh terhadap pekerja anak-anak yang bersangkutan, melainkan berpengaruh juga terhadap keluarganya. Pengaruh yang terjadi pada keluarga yaitu si pekerja anak menjadi terjauhkan dari keluarga. Banyaknya waktu yang diluangkan oleh pekerja anak dalam bekerja di bengkel sandal menyebabkan sedikitnya waktu untuk bercengkrama dengan keluarga. Sebagai contoh adalah kasus Suryadi (15 tahun).

"Suryadi (15 tahun), buruh di bengkel sandal, anak petani. Bengkel tempat ia bekerja cukup jauh dari rumah. Ia hanya berada di rumah pada saat akhir pekan karena pada senin hingga jumat ia bertempat tinggal di rumah temannya yang dekat dengan tempat kerja. Akhir pekan itu pun biasanya ia habiskan dengan bermain bersama temantemannya sehingga waktu yang ada untuk diluangkan bersama keluarga pun sangat terbatas."

Melihat peranan anak yang bekerja seperti yang diuraikan di atas, dapat ditarik suatu kesimpulan mengenai perlu atau tidaknya keterlibatan anak-anak dalam bekerja mencari nafkah. Keterlibatan anak-anak dalam bekerja yang umumnya untuk membantu ekonomi orangtuanya tidak terlihat secara nyata. Padahal, keterlibatan mereka dalam bekerja mengorbankan waktu sekolah mereka, yang sangat berguna bagi masa depan para anak-anak itu sendiri. Selain itu kondisi bengkel yang sedemikian rupa jelas berbahaya bagi kesehatan anak-anak itu sendiri. Pada usia dini mereka harus bersentuhan dengan lingkungan kerja yang rawan dan mengancam kesehatan mereka.

Perlu adanya upaya yang tegas untuk melarang keterlibatan anak-anak dalam bekerja di bengkel sandal. Hal ini menuntu kesadaran orangtua pekerja anak tersebut, pengusaha sandal dan aparat pemerintah setempat untuk menanggulanginya. Anak-anak harus disadarkan untuk lebih mencintai bangku sekolah ketimbang mencari nafkah.

\section{KESIMPULAN DAN SARAN}

Faktor-faktor yang memunculkan pekerja anak bila dilihat dari karakteristik pekerja anak itu sendiri adalah faktor pendidikan pekerja anak. Sementara bila dilihat dari karakteristik rumahtangga, nilai dan stigma sosial mempengaruhi timbulnya pekerja anak. Sosialisasi mengenai pekerjaan di bengkel alas kaki baik secara langsung maupun tidak langsung juga mendorong masuknya anak ke dunia kerja di bengkel sandal. Sementara itu dari karakteristik pekerjaan, dimana bengkel sandal termasuk ke dalam industri kecil sehingga mudah bagi pekerja anak dengan latar pendidikan yang rendah untuk masuk ke dalamnya. Keterampilan yang dibutuhkan pun bisa dipelajari dengan sendirinya.

Kontribusi pekerja anak terhadap pendapatan rumahtangga dapat dikatakan masih rendah karena dalam rumahtangga itu bisa jadi banyak anggota rumahtangga yang terlibat dalam pemenuhan kebutuhan rumahtangga. Pendapatan para pekerja anak rata-rata dialokasikan untuk memenuhi kebutuhan mereka sendiri. Seorang anak yang bekerja tidak diharuskan memberikan pendapatan yang diperolehnya dari bekerja di bengkel sandal kepada orangtua. Baru kemudian pada saat-saat yang mendesak mereka diharapkan membantu menyumbangkan pendapatannya untuk rumahtangga.

Pekerja anak terancam menurun kesejaheteraannya. Masalah utama yang pokok adalah masalah pendidikan para pekerja anak. Pendidikan pekerja anak yang rendah dan umumnya telah putus sekolah ditambah lagi mereka telah bekerja mengancam ketidakberlanjutan mereka di bangku sekolah.

Kondisi bengkel sandal tempat bekerja para pekerja anak cukup rawan bagi kesehatan anak-anak tersebut. Umumnya bengkel tempat mereka bekerja memiliki ventilasi udara yang kurang, ditambah lagi adanya debu dan uap di lingkungan tempat bekerja. Hal ini akan berdampak buruk bagi kesehatan mereka dalam jangka waktu yang cukup lama. Tak jarang pula pekerja anak berhubungan dengan bahan kimia yang dipakai untuk membuat sepatu seperti lem, bensin dan bahan kimia lainnya di tempat kerja yang mengancam kesehatan mereka.

Masalah kesehatan yang umumnya dialami oleh pekerja anak adalah luka ringan/ luka terbuka. Luka ini umumnya terjadi karena mereka menjahit bagian atas sepatu. Para pekerja anak pun telah menganggap biasa bila terluka. Masalah kesehatan lainnya yang cukup banyak terjadi adalah kelelahan yang sangat dan demam yang terjadi karena jam kerja anak tinggi bahkan tak jarang pekerja anak juga bekerja hingga larut malam untuk mengejar order. 
Bekerja di bengkel sandal bersama orang dewasa juga membawa perubahan secara emosional terhadap diri anak. Secara umum pekerja anak yang bekerja di bengkel sandal pernah mendapat perlakuan berupa sering diteriaki/ dibentak. Perlakuan ini mereka dapat ketika mereka melakukan kesalahan saat bekerja.

Anak meskipun harus terjun ke dunia kerja, mereka juga harus mendapatkan hak-hak mereka sebagai anak. Bagi pihak pengusaha atau pemilik bengkel sandal hendaknya lebih memperhatikan kelayakan upah yang diberikan sesuai dengan jenis pekerjaan. Para pemilik bengkel pun harus bisa menciptakan suasana kerja yang kondusif bagi anakanak, sehingga mereka dapat memperoleh hak mereka untuk bermain serta mendapat perlindungan kesehatan.

Kalangan akademisi dan LSM hendaknya juga berperan dalam melindungi anak-anak yang bekerja ini. Salah satunya dengan cara mengadakan penyuluhan terkait pentingnya pendidikan bagi anak-anak serta mengkomunikasikan berbagai bahaya yang mungkin didapatkan anak di tempat kerja. Melihat banyaknya status drop out pada sebagian besar pekerja anak, pemerintah hendaknya memperhatikan masalah pendidikan mereka terutama pemerintah di wilayah desa. Pendidikan non-formal bagi pekerja anak seperti adanya kejar paket $\mathrm{A}$ atau kejar paket B akan sangan membantu pekerja anak yang memiliki pendidikan yang rendah. Pendidikan non-formal ini tidak terikat oleh waktu sehingga tidak akan mengganggu waktu kerja pekerja anak.

\section{DAFTAR PUSTAKA}

Anonim. Household Income Definition. - . [Internet]. [diunduh 23 April 2011]. Dapat diunduh dari: http://www.investopedia.com/terms/h/household income.asp

Asih AW. 2007. Pekerja Anak dan Kontribusinya Bagi Pendapatan Rumahtangga (StudiKasus Pekerja Anak di Desa Cangkuang Kulon, Kecamatan Kolot, Kabupaten Bandung,Jawa Barat). [Skripsi]. Bogor [ID]: Progran Studi Ilmu Penyuluhan dan Komunikasi Pertanian. 105 hal.

[BPS, ILO] Badan Pusat Statistik, International labor Organization. 2009. Pekerja Anak di Indonesia 2009. [Internet]. [diunduh 7 Maret 2011]. Dapat diunduh dari: http://www.ilo.org/jakarta/whatwedo/ publications/lang--en/contLang--id/docNameWCMS 123584/index.htm.

[BPS] Badan Pusat Statistik. 2009. Peraturan Kepala Badan Pusat Statistik Nomor 57 Tahun 2009 Tentang Klasifikasi Baku Lapangan Usaha Indonesia. [Internet]. [diunduh 3 Februari 2012]. Dapat diunduh dari: http://www.bps.go.id/ download_file/kbli_2009.pdf

Charda SU. Perlindungan Hukum Ketenagakerjaan terhadap Tenaga Kerja Anak yang Bekerja Di Luar Hubungan Kerja Pada Bentuk Pekerjaan Terburuk. [Internet]. [diunduh pada 7 Maret 2011]. Dapat diunduh pada: http://isjd.pdii.lipi.go.id/admin/ jurnal/12210117134.pdf 18 hal.

Hasibuan, N. 1993. Ekonomi Industri : Persaingan, Monopoli dan Regulasi. LP3ES, Jakarta [ID]:

\section{LP3ES. 334 hal.}

[ILO] International Labor Organization. 2008. Panduan tentang Pelaksanaan Pemantauan dan Pelaporan Penerima Manfaat Langsung Proyek Pendukung Program Terikat Waktu Indonesia untuk Penghapusan Bentuk-bentuk Pekerjaan Terburuk untuk Anak - Tahap II. [Internet]. [diunduh pada 5 November 2011]. Dapat diunduh dari: http:// www.ilo.org/wcmsp5/groups/public/---asia/--ro-bangkok/---ilo jakarta/documents/publication/ wcms_124008.pdf.

[ILO] International Labor Organization. 2007. Pekerja Anak di Perkebunan Tembakau Sumatera Utara. [Internet]. [diunduh pada 6 Maret 2011]. Dapat diunduh dari: http://www.ilo.org/wcmsp5/ groups/public/---asia/---ro-bangkok/---ilo jakarta/ documents/publication/wcms_116527.pdf

Pitriyan P. 2006. The Impact of Child Labor on Child's Education: The Case of Indonesia [Internet]. [diunduh pada 7 Maret 2011]. Dapat diunduh dari: http://www.equitablepolicy.org/wpaper/200609. pdf. Priyambada A, Asep S, Sudarno S. What Happened to Child Labor in Indonesia during the Economic Crisis? The Trade-Off Between School and Work. [Internet]. [diunduh pada 7 Maret 2011]. dapat diunduh pada: http://unpan1.un.org/ intradoc/groups/public/documents/APCITY/ UNPAN018660.pdf.

Republik Indonesia. Undang-Undang Republik Indonesia Nomor 23 Tahun 2002 tentang Perlindungan Anak. [Internet]. [Diunduh Pada 7 Maret 2011]. Dapat diunduh pada: Http://Www.Komnasperempuan. Or.Id/WpContent/Uploads/2009/07/UUPERLINDUNGAN-ANAK.Pdf

Republik Indonesia. Undang-Undang Republik Indonesia Nomor 13 Tahun 2003 tentang Ketenagakerjaan. [Internet]. [Diunduh Pada 7 Maret 2011]. Dapat diunduh pada: Http://Sjsn.Menkokesra.Go.Id/ Dokumen/Peruu/2003/Uu13 2003 Ind.Pdf

Republik Indonesia. Keputusan Presiden No. 59/2002 Tentang Kesejahteraan Anak. [Internet]. [Diunduh Pada 7 Maret 2011]. Dapat Diunduh Pada: Http:// Hukum.Unsrat.Ac.Id/Uu/Uu_4_79.Htm

Republik Indonesia. Keputusan Presiden No 36/1990 Tentang Pengesahan Convention On The Rights Of The Child (Konvensi Tentang Hak-Hak Anak). [Internet]. [Diunduh Pada 7 Maret 2011]. Dapat Diunduh Pada: Http://Www.Hampapua.Org/Skp/ Hukum/Keppres36-1990i.pdf

Saleh IA. 1986. Industri Kecil : Sebuah Tinjauan Dan Perbandingan. Jakarta [ID]: LP3ES Indonesia. 157 hal.Singarimbun M, Effendi S. 1995. M e t o d e Penelitian Survai. Jakarta [ID]: PT Pustaka LP3ES Indonesia. 336 hal. 